
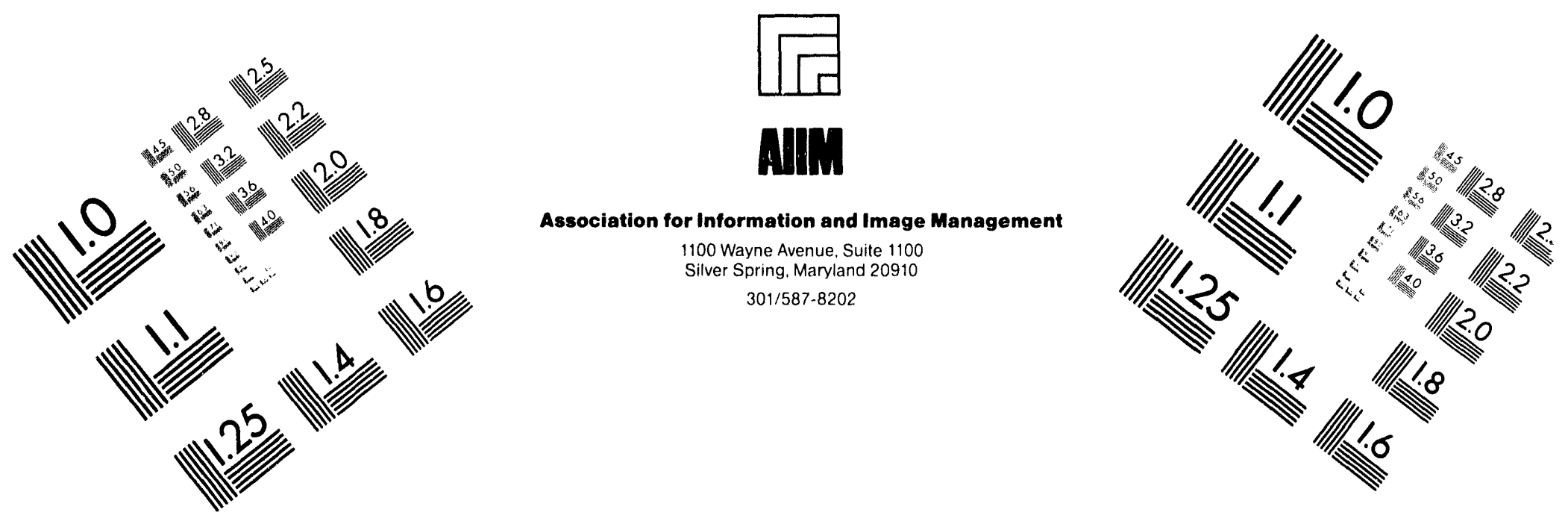

\title{
Centimeter
}

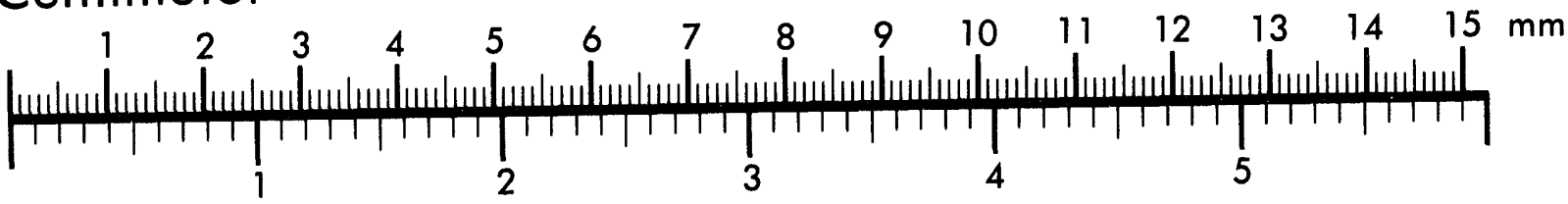

Inches
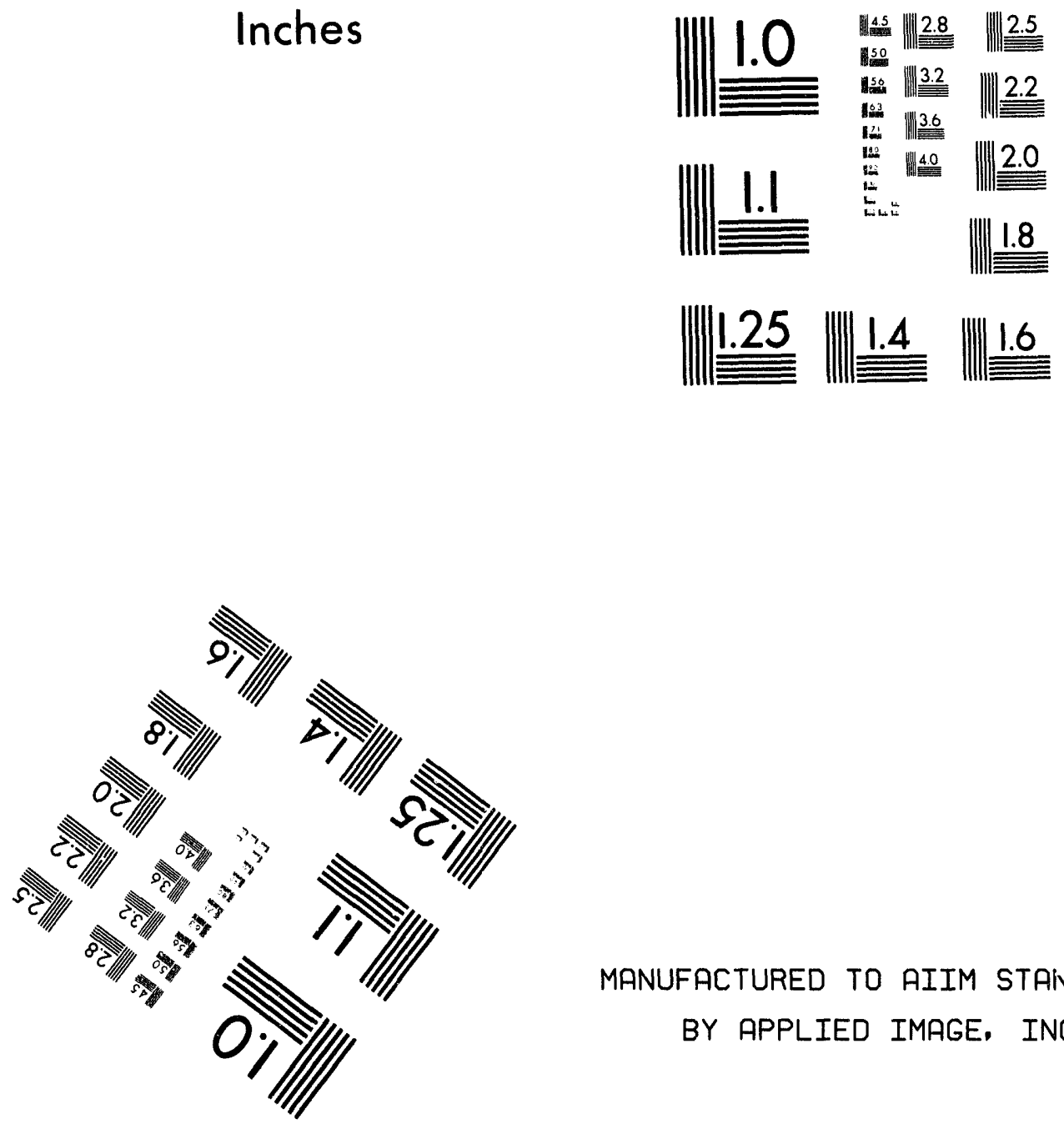

MANUFACTURED TO AIIM STAINDARDS

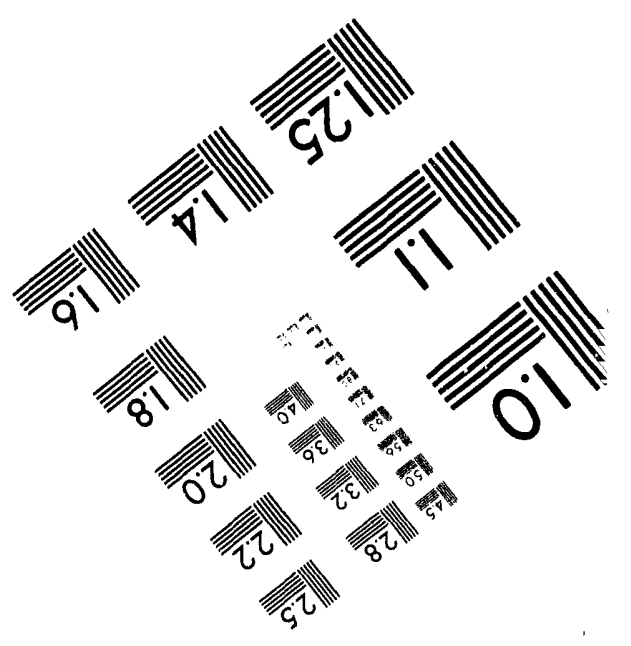



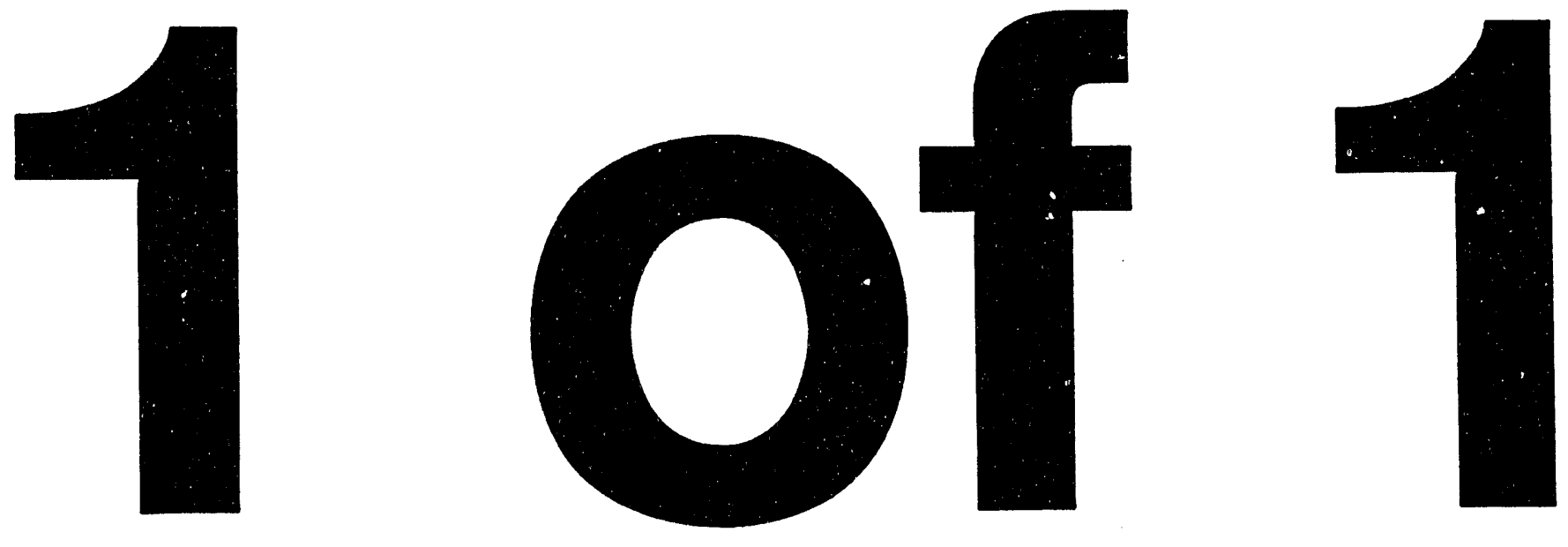
DOE/RL-94-77

UC-600

\section{Tritiated Wastewater Treatment and Disposal Evaluation for 1994}

Date Published

August 1994

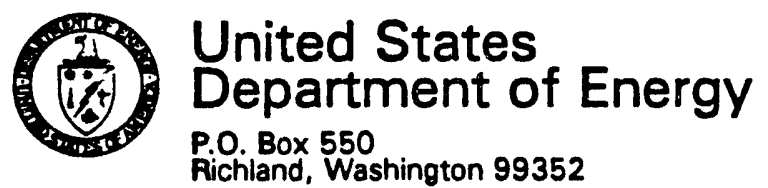

Richland, Washington 99352

Approved for Public Release MASTER

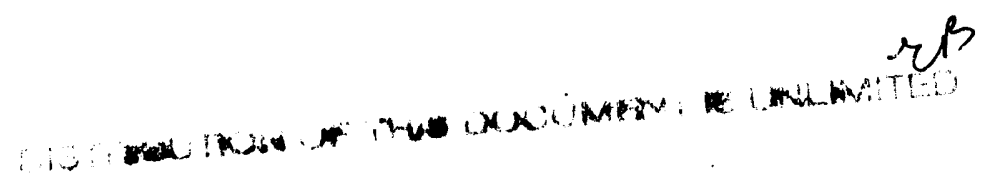




\section{EXECUTIVE SUMMARY}

This report discusses and analyzes information and issues regarding tritium and tritium management. It was prepared in response to the Hanford Federal Facility Agreement and Consent Order (Tri-Party Agreement) Milestone M-26-05A for the evaluation of tritiated wastewater treatment and disposal. The key elements of the report are summarized as follows:

Discharge of tritiated water is regulated worldwide. Differences exist in discharge limits and in regulatory philosophy from country to country and from state to state in the United States. Tritium from manmade sources is emitted into the atmosphere and discharged into the ground or directly to the oceans and to waterways that empty into the oceans. In 1989, reported worldwide emissions of tritium from nuclear power generating plants totaled almost 1,000,000 Curies ( $\mathrm{Ci}$ ).

Tritium is a radioactive isotope of hydrogen with many properties and characteristics similar to those of the other hydrogen isotopes. Because of its radioactive decay, $5.5 \%$ of all existing tritium is lost each year. Numerous processes have been developed to separate hydrogen isotopes in feed streams where tritium is at a high level and the feed volume is low. These technologies were reviewed. Efforts to develop unique methods for separating Jow levels of tritium in large feed volumes have not been fruitful. The most used process, Combined Electrolysis and Catalytic Exchange, was evaluated for potential in separating low levels of tritium in high feed volumes. None of these methods are presently deemed appropriate for separating tritium from liquid waste effluents because estimated capital and operating costs are too high. 
All processes that generated tritium at the Hanford Site have been terminated. Residual amounts of tritium from past operations are present in water contained in stored tank waste, in surface impoundments, and in the geological strata beneath of the Hanford Site. Discharge of treated effluent containing tritium to the soil column is planned for a site north of the 200 West Area. Modeling shows that time for potential migration of groundwater to the Columbia River from this site will allow tritium to decay to levels below the U.S. Environmental Protection Agency (EPA) Drinking Water Standard.

The Savannah River Site (SRS) is the other U.S. Department of Energy (DOE) location with major amounts of tritiated wastewater. Tritium is present in the groundwater at SRS in concentrations higher than at the Hanford Site. Treated effluent containing 5,000,000 $\rho \mathrm{Ci} / \mathrm{L}$ of tritium is directly discharged into a tributary of the Savannah River from the SRS-Effluent Treatment Facility (ETF).

The following three developments regarding tritium and tritium management deserve further study as subsequent annual reports are assembled: (1) is the ongoing research by Pacific Northwest Laboratory (PNL) in the membrane separation process for tritium; (2) 41 countries have accepted a formal ban on the sea dumping of low and intermediate radioactive waste. If tritium is included in this ban, it could stimulate development of tritium separation technology; and (3) on May 19, 1994, the U.S. Senate passed the Safe Drinking Water Act Amendments of 1994. The U.S. House of Representatives has not acted on this issue, thus, a final $l$ aw is not in place. The significance is that the $7 \mathrm{~W}$, when final, would force the EPA to prioritize the rulemaking on final Drinking Water Standards in which the contaminant level for tritium could be 
DOE/RL-94-77

reviewed and possibly raised to the recommended $60,900 \rho \mathrm{Ci} / \mathrm{L}$. 
DOE/RL-94-77

This page intentionally left blank. 


\section{CONTENTS}

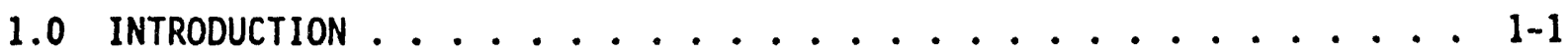

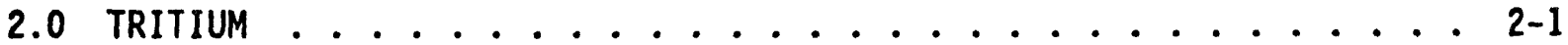

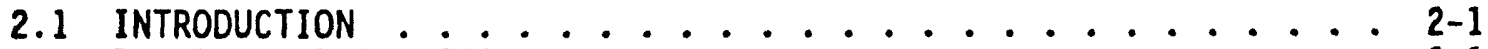

2.2 PHYSICAL PROPERTIES .................. 2-1

2.3 CHEMICAL PROPERTIES ................. 2-1

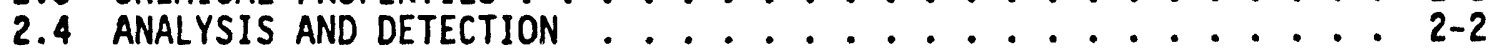

2.5 USES ................... 2- . . .

3.0 TRITIUM IN THE ENVIRONMENT ....................

3.1 NATURAL PRODUCTION AND OCCURRENCE ............ 3-1

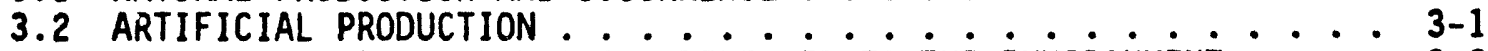

3.3 WORLDWIDE SURVEY OF TRITIUM RELEASED TO THE ENVIRONMENT . . . 3-2

3.3.1 Commercial Spent Fuel Reprocessing Facilities . . . . 3-2

3.3.2 Commercial Power Reactors . . . . . . . . . 3-2

3.3.3 Tritium Emissions from DOE Tritium Facilities . . . 3-3

3.3.4 Mechanisms for Disposal of Tritiated Wastewater . . 3-3

4.0 HEALTH RISKS ASSOCIATED WITH EXPOSURE TO TRITIUM . . . . . . . 4-1

4.1 TOXICITY ..................... 4-1

4.2 METABOLISM ....................... . . . . . .

4.3 EPIDEMIOLOGY . . . . . . . . . . . . . . . . . . . 4-2

4.4 OCCUPATIONAL EXPOSURE LIMITS .............. 4-2

5.0 REGULATION OF TRITIUM DISCHARGES ............. . . 5 .

5.1 GENERAL PRINCIPLES .................. . . . .

5.2 ESTABLISHING DISCHARGE LIMITS AND STANDARDS . . . . . . . . . 5-1

5.3 U.S. TRITIUM DISCHARGE LIMITS . . . . . . . . . . . . . 5-1

5.3.1 10 CFR $\$ 20$, Standards for Protection Against Radiation . 5-2

5.3.2 10 CFR \$50, Appendix I, Design Requirements for Nuclear Reactors ................ 5-2

5.3.3 40 CFR \$141, National Primary Drinking Water Regulations and Chapter 173-200 Washington Administrative Code (WAC), Water Quality Standards for Groundwater of the State of Washington............. 5-2

5.3.4 40 CFR \$190, Environmental Radiation Protection Standards for Nuclear Power Plant Operations . . . . 5-3

5.4 RADIATION DOSE AND TRITIUM DISCHARGE LIMITS FOR OTHER

COUNTRIES . . . . . . . . . . . . . . 5-3

5.4.1 United Kingdom (UK) ..........................

5.4.2 France... . . . . . . . . . . . . 5-4

5.4 .3 Germany .................. 5-4

5.4 .4 Canada .................. 5-5

5.4 .5 Russia................... 5-5

5.4 .6 Japan .................. . . 5-5

6.0 TRITIUM SEPARATION TECHNOLOGIES ............... . . 6-1

6.1 HYDROGEN ISOTOPE SEPARATION . . . . . . ....... 6-1

6.1.1 Enrichment Technology ............. . 6-1

6.1.2 Physical Processes ................ 6-4

6.1.3 Chemical Processes............... 6-4 
6.1.4 Combination Processes ............ 6-5

6.1.5 Other Processes . . . . . . . . . . . . . 6-5

6.2 POTENTIAL APPLICATION OF TRITIUM SEPARATION TECHNOLOGIES . . . 6-5

6.3 FUTURE DEVELOPMENT OF POTENTIALLY FEASIBLE SEPARATION

TECHNOLOGY .................... 6-8

7.0 TRITIUM AT THE HANFORD SITE ............... . . . .

7.1 TRITIUM CONTAMINATION IN HANFORD SITE GROUNDWATER $. . . . .7-1$

7.1.1 Source of Tritium in Groundwater . . . . . . . . . 7-1

7.1.2 200 East Area Tritium Plume ............ . 7-1

7.1.3 200 West Area Tritium Plume ............. 7-3

7.1.4 100 Area Tritium Groundwater Plumes .......... 7-3

7.1.5 Surface Impoundments .......... 7-5

7.2 TREATMENT OF AQUEOUS WASTE CONTAINING LOW-LEVEL RADIATION . . 7-5

7.2.1 200 Area ETF Treatment Process . . . . . . . . . . . 7-5

7.2.2 Composition of Permitted and Candidate Feed Streams . . 7-6

7.2.3 Projected Discharge of Tritium ....... . . . .

7.2.4 Potential Reuse Options for Tritiated Water at the Hanford Site......... 7-8

7.3 DISCHARGE OF TRITIATED WASTEWATER TO THE HANFORD SITE SOIL

COLUMN . . . . . . . . . . . . . . . . . 7-8

7.3.1 Disposal Options Considered in the Selection of Soil Column Disposal ................ . . 7-9

7.3.2 Groundwater Modeling Done to Support Selection of the Disposal Site................. 7-10

8.0 TRITIUM AT THE SAVANNAH RIVER SITE ............ 8-1

8.1 EXTENT OF THE TRITIUM CONTAMINATION AT SRS ..........

8.2 TRITIUM MANAGEMENT AT SRS . . . . . . . . . . . . . 8-2

8.3 PERMIT CONDITIONS FOR DISCHARGE OF TRITIATED WASTEWATER AT SRS 8-2

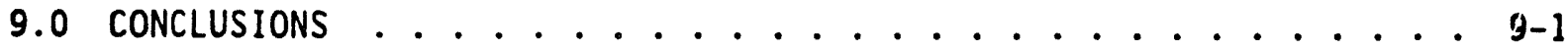

10.0 REFERENCES ....................... . . . . . . . . . APPENDICES:

APPENDIX A TRI-PARTY AGREEMENT MILESTONE M-26-05A TRITIATED WASTEWATER TREATMENT EVALUATION ............ A-i

APPENDIX B CONVERSION TABLES ................. B-i 


\section{LIST OF FIGURES}

2-1. Tritium Decay ...................... 2-3

6-1. Conceptual Tritium Separations Cascade System . . . . . . . 6-3

6-2. Degree of Separation . . . . . . . . . . . . 6-7

7-1. Tritium $\left({ }^{3} \mathrm{H}\right)$ Concentrations in the Unconfined Aquifer, $1992 \ldots 7-2$

7-2. Tritium Concentration Trend in Well 299-W22-9......... 7-4

7-3. 200 Area ETF Process Schematic . . . . . . . . . 7-7

7-4. Location of Final Three Candidate Sites . . . . . . . 7-12

7-5. Simulated Hydraulic Head Contours with Disposal at the

State-Approved Land Disposal Site ........... . . 7-13

\section{LIST OF TABLES}

2-1. Tritium Decay . . . . . . . . . . . . . . . 2-3

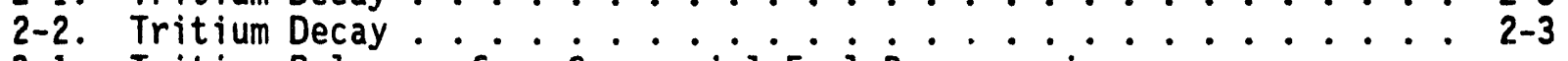

3-1. Tritium Releases from Commercial Fuel Reprocessing Facilities (SAIC 1994) ................ 3-3

3-2. Commercial Power Reactor Emissions (SAIC 1994) . . . . . . . 3-4

3-3. Releases of Tritium at Department of Energy Tritium

Management Facilities.................. 3-5

5-1. United States Regulatory Limits on Radioactive Exposure to the Public and Release of Tritium . . . . . . . . . . . 5-2

6-1. Total Separation of Each Processing Stage .............. $6-4$

7-1. Results of Cost/Risk Evaluation .............. . . . . . . . .

B-2. Radioactivity Level Conversions . . . . . . . . . . . B-1 
DOE/RL-94-77

This page intentionally left blank. 
Frequently Used Abbreviations and Acronyms

$\begin{array}{ll}\text { AECL } & \text { Atomic Energy of Canada Limited } \\ \text { CFR } & \text { Code of Federal Regulations } \\ \text { DOE } & \text { U.S. Department of Energy } \\ \text { DST } & \text { double-shell tank } \\ \text { ECology } & \text { Washington State Department of Ecology } \\ \text { EPA } & \text { U.S. Environmental Protection Agency } \\ \text { ETF } & \text { Effiuent Treatment Facility } \\ \text { ICRP } & \text { International Commission on Radiological Protection } \\ \text { LERF } & \text { Liquid Effluent Retention Facility } \\ \text { PNL } & \text { Pacific Northwest Laboratory } \\ \text { PUREX } & \text { Plutonium-Uranium Extraction } \\ \text { REDOX } & \text { reduction oxidation } \\ \text { SRS } & \text { Savannah River Site } \\ \text { SST } & \text { Single-sheli tank } \\ \text { Tri-Party } & \text { Agreement Hanford Federal Facility Agreement and Consent order }\end{array}$


Scientific Symbols and Abbreviations

Elements and Compounds

Symbol

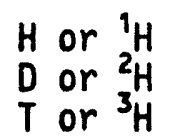

$\mathrm{He}$

$\mathrm{H}_{2}$

$\mathrm{D}_{2}^{2}$

HD

HT

DT

$\mathrm{H}_{2} \mathrm{O}$

$\mathrm{D}_{2}^{2} \mathrm{O}$

$\mathrm{T}_{2}^{2} \mathrm{O}$

HDO

HTO

DTO

${ }_{12}^{14} \mathrm{~N}$

${ }_{i}^{12} \mathrm{C}$

${ }_{90}^{127} \mathrm{I}$

Units of Measure

Unit

\section{L}

m

g

W

$h$

${ }^{\mathrm{K}} \mathrm{C}$

$\mathrm{Ci}$

$\mathrm{Bq}$

Gy

SV

\section{Definition}

Hydrogen

Deuterium

Tritium

Helium

Hydrogen, elemental

Deuterium, elemental

Tritium, elemental

Mixed isotopic hydrogen, elemental

Mixed isotopic hydrogen, elemental

Mixed isotopic hydrogen, elemental

Water

Deuterium oxide or heavy water

Tritium oxide

Mixed isotopic water

Mixed isotopic water (tritiated water)

Mixed isotopic water

Nitrogen

Carbon

Neutron

Iodine-127

Strontium-90

\section{Definition}

\section{Liter}

Meter

Gram

Watt

Hour

Degree Kelvin (absolute temperature)

Degree Centigrade

Curie

Bequere 1

Grey (100 rads)

Sievert (100 rems) 
Magnitude Modifiers

$\begin{array}{lll}\text { Symbol } & \text { Unit } & \text { Amount } \\ K & \text { Kilo } & 10^{3} \\ M & \text { Mega } & 10^{6} \\ T & \text { Tera } & 10^{12} \\ m & \text { milli } & 10^{-3} \\ \mu & \text { micro } & 10^{-6} \\ \rho & \text { pico } & 10^{-12}\end{array}$




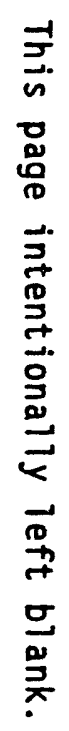




\subsection{INTRODUCTION}

This report is the first response to the Hanford Federal Facility Agreement and Consent order (Tri-Party Agreement) Milestone M-26-05A, Tritiated Wastewater Treatment Evaluation. It includes timely information, summaries, analyses, and discussions on a number of aspects and issues regarding tritium at the Hanford Site.

As the first in a series, it combines a summary of past history with an analysis of the most current events dealing with tritium. The body of literature reviewed in preparing these summaries and analyses is therefore much larger than that envisioned for subsequent annual "updates." The restricted length of the report required that some topics be emphasized and others be made more general. This allows future reports to build on the foundation of this report, providing details on topics that received only general analysis. A copy of the Tri-Party Agreement Milestone is included as Appendix A.

This report emphasizes the topics of tritium decay, tritium separation, and the disposal of tritiated wastewater into the soil column at the Hanford site. The report intends to communicate highly technical concepts in layman's terms. But because of the technical nature of separation processes, Section 6.0 becomes somewhat complex. Consequently, this section is approached in more of a teaching style.

Information for this report was compiled almost entirely from published, documented materials to establish a technical basis for ongoing efforts to understand tritium.

The "Curie" is a special unit of measure used in the U.S. to express an amount of radiation or an amount of radioactive material based on its radioactivity. One Curie $(\mathrm{Ci})$ is $3.7 \times 10^{10}$ disintegrations per second.

of all the combinations of units possible for expressing concentrations of tritium in water, the term "picocuries per liter" ( $\rho \mathrm{Ci} / \mathrm{L})$ seems to have become standard terminology at the Hanford Site. It is used almost exclusively in this report. Where regulatory limits are expressed in other units, this report cites the actual 1 imit and in parenthesis gives the conversion to our common usage. Appendix B shows equivalencies of concentration measurements. 


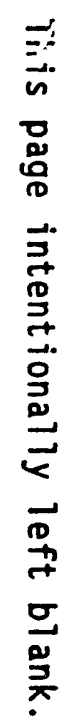

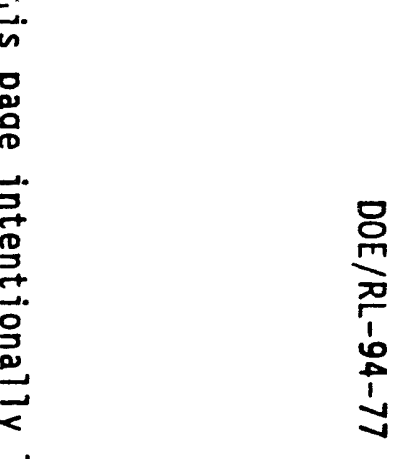




\subsection{TRITIUM}

\subsection{INTRODUCTION}

"Tritium" is the name assigned to the third member of the hydrogen isotope series. Its nucleus consists of one proton and two neutrons resulting in an atomic mass of three. The symbol for tritium is " $H^{3}$ but " $T$ " is used more often as a scientific abbreviation. Because of the high ratio of neutrons to protons, the tritium nucleus is unstable and radioactively decays with a half-life of 12.3 years. Therefore, $5.5 \%$ of all existing trjtium is lost in 1 year by radioactive decay. The product of this decay is $3 \mathrm{He}$ and a low energy beta particle. Figure 2-1 and Tables 2-1 and 2-2 show the decay rate for tritium.

Tritium occurs in nature only to the extent that it is in equilibrium with amounts that are naturally produced by cosmic rays and are manmade as byproducts of nuclear processes.

The second isotope of hydrogen is deuterium. Its scientific symbol is "2 $\mathrm{H}$ " but the abbreviation "D" is more common usage.

\subsection{PHYSICAL PROPERTIES}

Relative to hydrogen, the larger atomic mass of elemental tritium causes its physical properties to be somewhat higher than hydrogen. For example, $T_{2}$ boils at $25 \mathrm{~K}$ relative to $20 \mathrm{~K}$ for $\mathrm{H}_{2}$. Tritium oxide $\left(\mathrm{T}_{2}, 0\right)$ boils at $101.5^{\circ} \mathrm{C}$ compared to $100.0^{\circ} \mathrm{C}$ for normal water $\left(\mathrm{H}_{2} \mathrm{O}\right)$. The specific gravity of $\mathrm{T}_{2} \mathrm{O}$ is 1.2 times greater than that for $\mathrm{H}_{2} \mathrm{O}$. These differences in physical properties have been exploited for the separation of hydrogen isotopes (see Section 6.1).

\subsection{CHEMICAL PROPERTIES}

Most chemical properties of tritium are common with those of other hydrogen isotopes. Tritium gas burns in oxygen to form $\mathrm{T}_{2} \mathrm{O}$, and it exchanges with hydrogen atoms of organic molecules.

The differences in chemical behavior of isotopes, called isotope effects, are observed for the hydrogen series. For example, free tritium exchanges quite readily with bound hydrogen. Because the tritium atom is heavier than the hydrogen atom, bound tritium is slightly more stable than hydrogen bound in the same chemical environment. A comparison of the ionization constants of $\mathrm{T}_{2} \mathrm{O}$ and $\mathrm{H}_{2} \mathrm{O}$ illustrates this difference. The constant for $\mathrm{H}_{2} \mathrm{O}$ is $1 \times 10^{-14}$ and

$6 \times 10^{-16}$ (17 times smaller) for $T_{2} 0$. Therefore, under conditions of competitive exchange, tritium in the bound form is favored over hydrogen. This difference becomes the basis for the chemical isotopic separation schemes that are discussed in Section 6.1.3. 


\subsection{ANALYSIS AND DETECTION}

Tritium is readily detectable at low levels because of its radioactivity. Concentrations as $10 \mathrm{w}$ as $10 \mathrm{\rho Ci} / \mathrm{L}$ in water can be detected under certain conditions. Liquid scintillation counting is a rapid and sensitive method applied to determire the amount of tritium in liquid samples. The ionization chamber is sensitive to the detection of tritium in gaseous form. Mass spectrometry is most useful for distinguishing between compounds containing mixed hydrogen isotopes, such as HD, HT and DT or HDO, HTO, and DTO.

When tritium concentrations are near the detection limit of the method, accuracy can be improved by increasing the specific activity of the sample. This is accomplished by using laboratory-scale isotopic enrichment processes. Electrolysis and distillation are particularly effective for laboratory enrichment of tritium in water samples. Thermal diffusion and gas chromatography provide similar laboratory enrichment of gaseous hydrogen samples. For more information on the properties of tritium, see Katz (1978) and Vasaru (1993).

\subsection{USES}

If fusion power is developed and used in the future, it will be a major commercial application for tritium. Presently, the major commercial use for tritium is in radioluminous light sources. In these applications, beta emission from tritium activates a luminescent phosphor causing the emission of light. This light is used to illuminate signs where there is no electrical power. Glowing "EXIT" signs are a prime exaniple of this use. Some of the tritium $(1,000,000$ to $2,000,000 \mathrm{Ci})$ separated from heavy water reactor media in Canada is used for this purpose. About 20 to $30 \mathrm{C} i$ of tritium are used in a typical sign. Small amounts of tritium are used as a radiotracer in medical and laboratory work. 
DOE/RL-94-77

Figure 2-1. Tritium Decay.

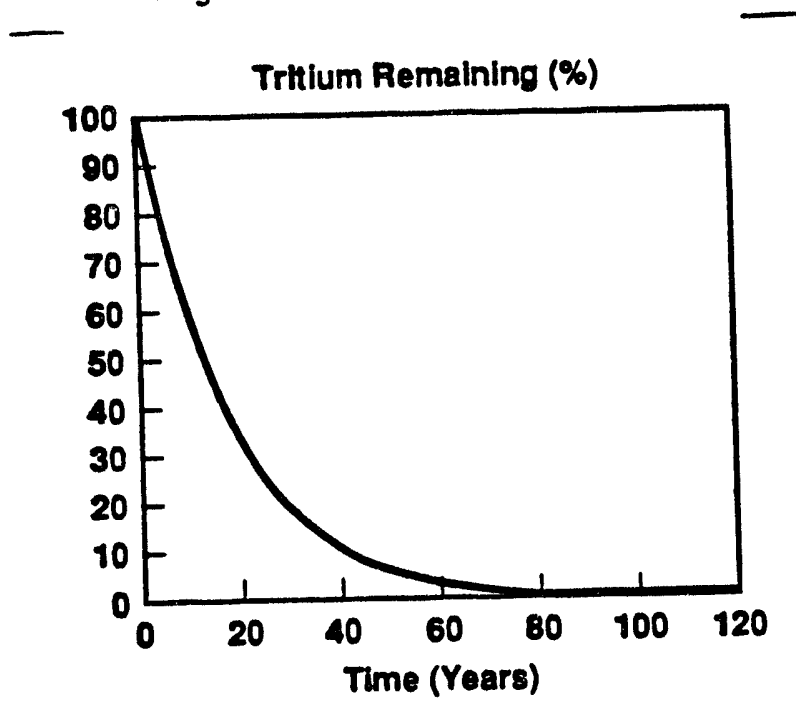

H9407028.1

Table 2-1. Tritium Decay.

\begin{tabular}{cc}
\hline $\begin{array}{c}\text { Decay Time, } \\
\text { Years }\end{array}$ & $\begin{array}{c}\text { Tritium } \\
\text { Remaining }(\%)\end{array}$ \\
\hline 0 & 100. \\
10 & 57.0 \\
20 & 32.5 \\
30 & 18.5 \\
40 & 10.6 \\
50 & 6.03 \\
60 & 3.44 \\
70 & 1.96 \\
80 & 1.12 \\
90 & 0.64 \\
100 & 0.36 \\
110 & 0.21 \\
120 & 0.12 \\
\hline
\end{tabular}

Table 2-2. Tritium Decay.

\begin{tabular}{cc}
\hline $\begin{array}{c}\text { Tritium } \\
\text { Remaining }\end{array}$ & $\begin{array}{c}\text { Decay Time, } \\
\text { Years }\end{array}$ \\
\hline 1.0 & 0 \\
0.1 & 41 \\
0.01 & 82 \\
0.001 & 123 \\
0.0001 & 164 \\
0.00001 & 205 \\
\hline
\end{tabular}


This page intentionally left blank. 


\subsection{TRITIUM IN THE ENVIRONMENT}

\subsection{NATURAL PRODUCTION AND OCCURRENCE}

Tritium arises in nature primarily by the interaction of cosmic rays (high energy protons and neutrons) with nitrogen and oxygen in the upper atmosphere. The most common is the reaction with nitrogen.

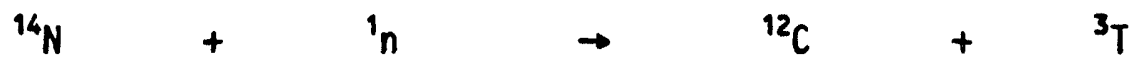

About 4 Megacuries/year (1 Megacurie, MCi, equals 1,000,000 Ci) are produced in this way. The accepted estimate of the steady-state global inventory of natural tritium is about $30 \mathrm{MCi}$. This is equivalent to about 3 $\mathrm{Kg}$ of elemental tritium $(10,000 \mathrm{Ci}$ is $1.03 \mathrm{~g}$ of tritium). Recent calculations indicate that this inventory could be as high as $100 \mathrm{MCi}$ (Vasaru 1993).

\subsection{ARTIFICIAL PRODUCTION}

In addition to naturally produced tritium, artificial sources contribute substantially to the present world inventory. From 1950 to 1963 , it is estimated that atmospheric testing of thermonuclear devices added about $120 \mathrm{Kg}$ of tritium (about 1,000 MCi) to the natural inventory (Vasaru 1993).

Tritium is also produced as a byproduct of fission in nuclear reactors. During reactor operation, tritium is formed in the fuel element by a process called ternary fission. In ternary fission, a nucleus is split into three particles. In operating reactors, a ternary fission generating an atom of tritium occurs randomly once in just over a thousand atomic fissions.

A second source of tritium from nuclear operations occurs in heavy water $\left(D_{2}(0)\right.$ moderated reactors. The high neutron flux in the core of these reactors slowly converts some of the deuterium to tritium. To maintain moderator efficiency, the $\mathrm{D}_{2} \mathrm{O}$ is regularly processed to remove this tritium (see Section 6.0).

Tritium, produced by ternary fission in the reactor core, may escape into ventilated areas and subsequently be emitted in air effluent or released as tritiated water and emitted in liquid reactor effluent. During operations, fuel rods with stainless steel cladding may lose up to half the tritium produced in ihe fuel by diffusion and permeation through the cladding. With Zircalloy-clad fuel, essentially all the tritium is retained in the fuel rod as zirconium tritide. Subsequent processing of the spent fuel releases $T_{2}$ or HT gas to the atmosphere and dilute HTO in several aqueous process effluent streams.

Once formed or released in the atmosphere, tritium either reacts with oxygen or exchanges with hydrogen in water vapor to form tritiated water 
(HTO). Therefore, $99 \%$ of the world inventory of tritium resides in the earth's hydrosphere. The remaining $1 \%$ exists in the atmosphere as HT gas or HTO vapor.

$$
\begin{array}{lll}
\mathrm{T} \cdot+\mathrm{H}_{2} \mathrm{O} & \rightarrow \\
\mathrm{T} \cdot \mathrm{HTO}+\mathrm{H} & +\mathrm{HT}
\end{array}
$$

\subsection{HORLOWIDE SURVEY OF TRITIUM RELEASED TO THE ENVIRONMENT}

In preparing this report, a survey was conducted to establish a reference baseline to compare anticipated tritium emissions from Hanford Site waste processing and remediation activities to the emissions from other known U.S. and international sources. Information on historical airborne and liruid tritium emissions from other point sources was compiled and assessed (SAIC 1994).

This survey focused on tritium releases from several processes related to the production of nuclear weapons, nuclear power generation, and radioisotope production. These sources are similar to Hanford Site waste management and remediation activities in that the tritium emissions are continuous, planned, and regulated point-sources.

The 1993 Report of The United Nations Scientific Committee on the Effects of Atomic Radiation titled Sources and Effects of Ionizing Radiation (UNSCEAR 1993), contains a comprehensive compilation of information on radioisotope releases. The report was issued in early 1994 and includes data on airborne and liquid releases of radioisotopes from nuclear industry sources in 26 countries from 1985 through 1989. The report contains substantial data on emissions from commercial reactor and fuel reprocessing facilities. Unfortunately, although the report was issued recently, the information in it is 5 years old.

\subsubsection{Commercial Spent Fuel Reprocessing Facilities}

Fuel reprocessing facilities are major sources of tritium releases. A summary of releases from 1985 to 1989 for Cap de la Hague in France, Sellafield in the UK, and Tokai-Mura in Japan is shown in Table 3-1. Fuel reprocessing activities outside the U.S. in 1989 accounted for $180,000 \mathrm{Ci}$ of tritium reported in both airborne and 1 iquid releases, with almost $90 \%$ released as liquid.

\subsubsection{Cormercial Power Reactors}

Reported global emissions of tritium from nuclear power plants totaled to almost $500,000 \mathrm{Ci}$ in 1989 (see Table 3-2). Of this, $40 \%$ was discharged into water and $60 \%$ discharged into the air. The most significant global sources of tritium emissions were the heavy water reactor (HWR) sites in Canada, Argentina, India, and Pakistan. These 11 HWR reactor sites, of 242 iisted, accounted for $70 \%$ of the tritium emissions reported. Canada, with six HWR locations, contributed $40 \%$ of the worldwide emissions of tritium. 
Table 3-1. Tritium Releases from Commemcial Fuel Reprocessing Facilities (SAIC i 994 ).

\begin{tabular}{|l|c|c|c|c|c|}
\hline \multirow{2}{*}{ FACILITY } & \multicolumn{5}{|c|}{ LIQUID RELEASES OF TRITIUM FROM REPROCESSING } \\
& \multicolumn{5}{|c|}{ PLANTS (CURIES) } \\
\cline { 2 - 6 } & 1985 & 1986 & 1987 & 1988 & 1989 \\
\hline Cap de La Hague France & 70,270 & 62,162 & 81,081 & 67,568 & 100,000 \\
Sellafield, United Kingdom & 28,703 & 58,108 & 37,162 & 46,595 & 57,946 \\
Tokai-Mura, Japan & 7,027 & 6,486 & 7,027 & 2,000 & 6,486 \\
\hline
\end{tabular}

In comparison, the U.S., with 88 pressurized water reactor (PWR) and boiling water reactor (BWR) facilities, was responsible for $8 \%$ of the world emissions of tritium in 1989.

European countries near the Atlantic Ocean report emissions of $33,000 \mathrm{Ci}$ of tritium from 69 reactors.

\subsubsection{Tritium Emissions from DOE Tritium Facilities}

Tritium releases from the U.S. Department of Energy (DOE) Tritium Facilities that engage in Research and Development activities, production, processing, shipment, and storage of tritium have been reported (DOE 1991). Over the last decade, releases of tritium at all locations engaged in these activities show a continuing decline (see Table 3-3).

Because of manufacturing and processing, the Savannah River site (SRS) is by far the most significant contributor of tritium emissions. These emissions from SRS do not include emissions from plutonium reactor and fuel reprocessing areas.

Consistent with the as low as reasonably achievable (ALARA) philosophy, the tritium control method in place at all locations is "the reduction of releases by continually improving operations."

\subsubsection{Mechanisms for Disposal of Tritiated Wastewater}

European countries typically discharge tritiated water into the Atlantic Ocean. According to the 1972 London Convention, waste containing up to $1,000,000$ total Ci per ton of waste is approved for ocean disposal. The North Atlantic area limit for total radioactive disposal was set at $10^{15} \mathrm{Ci} /$ year. Russia (the former USSR) discharges its low-level radioactive waste into the Sea of Japan and into the Arctic Ocean at Murmansk. In India, tritiated waste is pumped to ponds for solar evaporation (IAEA 1984). 
Table 3-2. Commercial Power Reactor Emissions (SAIC 1994).

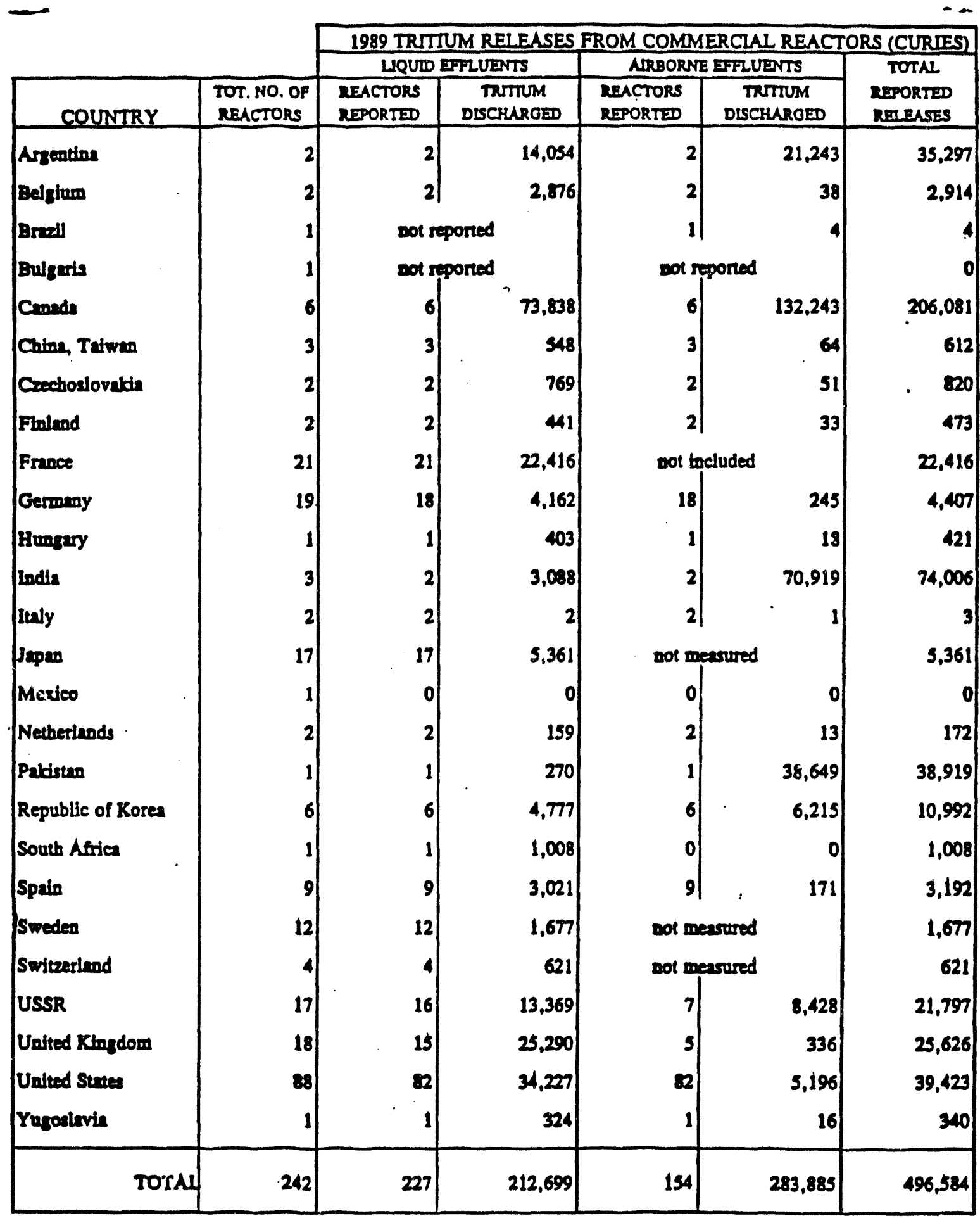


Table 3-3. Releases of Tritium at DOE Tritium Management Facilities.

\begin{tabular}{lccccc}
\hline Location & 1986 & 1987 & 1988 & 1989 & 1990 \\
\hline & & & & & \\
LLNL & 1,128 & 2,634 & 3,978 & 2,949 & 1,283 \\
LANL & NA & NA & 10,672 & 13,464 & 6,393 \\
Mound Plant & 3,601 & 3,979 & 3,319 & 2,802 & 40,777 \\
ORNL & 30,690 & 43,560 & 20,664 & 25,200 & 11,900 \\
Pantex Plant & 0.13 & 0.10 & 0.12 & 40,000 & 2,550 \\
Pinellas Plant & 198 & 181 & 296 & 117 & 125 \\
SRS (H Area and & 406,700 & 551,900 & 389,000 & 364,200 & 248,900 \\
tritium & & & & & \\
reactors) & & & & & \\
\hline
\end{tabular}

LLNL = Lawrence Livermore National Laboratory

LANL = Los Alamos National Laboratory

ORNL = Oak Ridge National Laboratory 
DOE/RL-94-77

This page intentionally left blank. 


\subsection{HEALTH RISKS ASSOCIATED WITH EXPOSURE TO TRITIUM}

\subsection{TOXICITY}

The maximum energy of beta emission from tritium decay is $18.6 \mathrm{keV}$. This produces a maximum track length for tritium beta travel of $6 \mu \mathrm{m}$ in water. Because it can never penetrate the outer layers of skin, beta radiation from tritium decay only inflicts damage to humans when tritium is present inside the body. Commonily used monitors, such as film badges or thermoluminescence dosimeters that detect and measure external exposure to radiation, do not detect tritium in the body.

Radioactivity, by low energy beta emission, is the only biological hazard characteristic of tritium. Because tritium as HTO is not distinguisher from water by living systems, it does not concentrate in a specific organ as does iodine-127 or strontium-90. Also, like hydrogen, it possesses no intrinsic chemical toxicity.

\subsection{METABOLISM}

Tritiated water, which is incorporated into the body by inhalation, ingestion, or absorption, will partition into three biological systems or "compartmerits." The first compartment is the water contained within body cells and systems. Tritium, as HTO, has a biological half-life of about 10 days in this compartment. This is called "iissue free water" tritium (TFWT). Organically bound tritium (OBT), the second compartment, results from the exchange of tritium with hydrogen bound to carbon. The OBT has a biological half-life of 30 days. The third compartment is the OBT present in lipids and fatty tissue where the biological half-life is 450 days. The substantially lower exchange rate for tritium into this last compartment results from the lower interaction of water with "oily" surfaces of fatty tissues and lipids.

Biological half-lives for tritium in different body systems reoresent physical and chemical processes within the body and not the nuclizar decay of tritium. As such, they represent the rate of chemical exchangeability of tritium both into and cut of the biological system components. Biological half-lives vary from individual to individual. Those reported above are assumed averages for the adult male.

The first biological component, TFWT, is responsible for about $90 \%$ of a total absorbed dose, while the second and third systems together account for the remaining $10 \%$ of the tritium dose. When a person is contaminated, the National Council on Radiation Protection and Measurement recommends "oral intake of fluid (e.g., water, fruit juice, tea, coffee, or beer) at 3 to 4 L/day" (Okada and Momoshima 1993) to dilute and flush tritium out of body systems, particularly before it assimilates into the more isolated systems.

The internal hazard from exposure to molecular tritium (HT or $\mathrm{T}_{2}$ ) is much less severe than that of HTO. Only $0.004 \%$ of HT inhaled by a human is converted to HTO and retained in the body compared to 98 to $99 \%$ retention for inhaled HTO. Neither HT nor $\mathrm{T}_{2}$ is absorbed through the skin, whereas HTO is 
taken into the body both by absorption and inhalation. The relative dose effect for exposure to HT is about $1 / 10,000$ that for HTO.

\subsection{EPIDEMIOLOGY}

Once in the environment, tritium as HT or HTO is easily transported and rapidly diluted. Several instances of accidental emission of tritium at Savannah River and Lawrence Livermore National Laboratory showed that releases of 30,000 to $500,000 \mathrm{Ci}$ of elemental tritium to the environment imposed little health risk. The calculated maximum human exposure inside the plant boundary for a 30,000-Ci release of HTO was $3.0 \mathrm{mSV}(0.3 \mathrm{milli}$ rem) (Okada and Momoshima 1993).

Two epidemiological studies of long-term exposure of workers to tritium in atomic facilities in the United Kingdom have been reported (Beral et al. 1985, 1988). These studies reveal a possible correlation of increased worker death from prostate cancer that might be related to internal exposure to tritium. Further studies are needed to confirm the result because of the overall low death rate of workers in the study.

\subsection{OCCUPATIONAL EXPOSURE LIMITS}

For purposes of radiation protection, the International Commission on Radiological Protection (ICRP) established $3 \times 10^{9}$ bequerels (Bq) (about 0.08 Ci) (ICRP 1991b) as the annual limit for intake of tritiated water. The Derived Air Concentration (DAC) limit for HTO established by the ICRP is $8 \times$ $10^{5} \mathrm{~Bq} / \mathrm{m}^{3}$ (about $22 \mu \mathrm{Ci} / \mathrm{m}^{3}$ ) (ICRP 1978). Because tritium gas, $\mathrm{T}_{2}$, or $\mathrm{HT}$ is less radiotoxic than HTO and is much less likely to be absorbed into the body from an exposure, its DAC limit is $2 \times 10^{10} \mathrm{~Bq} / \mathrm{m}^{3}\left(0.5 \mathrm{ci} / \mathrm{m}^{3}\right)$ (ICRP 1978).

The December 1993 issue (Vol. 65, No. 6) of Health Physics deals with risk assessment, dosimetry, metabolism, and radiobiology of tritium. Refer to Health Physics and International Atomic Energy Commission (IAEA 1991) for further information on these subjects. 


\subsection{REGULATION OF TRITIUM DISCHARGES}

\subsection{GENERAL PRINCIPLES}

Radioactivity, expressed in $\mathrm{Ci}$ or $\mathrm{Bq}$, is a measure of the rate of decay of atomic nuclei in a radioactive substance. It is used as the bas is to quantify the energy imparted to an exposed subject. This energy is expressed in units of rads or gray (Gy) ( 100 rad is 1 Gy). Effective radiation dose, expressed in rems or sieverts (SV) (100 rems is 1 SV) is the quantified effect of ionizing radiation on humans.

Radioactivity discharge limits are imposed either as limits to the amount of potential exposure to radiation or as limits to the amount of radioactivity discharged. Radioactivity exposure limits are established by anticipating annual total-body dose to members of the public who will likely be exposed to radioactivity emitted from the regulated source. This is expressed as a total-body dose 1 imit in millirem/year (mrem/year). This dose limit may be established for a specific radionuclide, or it may be established for a group of radionuclides (e.g., beta emitters).

Alternatively, limits on radioactivity in discharges are expressed as total activity per unit time (e.g., Bq/year) or as activity concentrations (e.g., $\rho C i / L)$.

\subsection{ESTABLISHING DISCHARGE LIMITS AND STANDARDS}

Discharge limits for radionuclides, whether expressed by dose or activity, may be established as general standards (e.g., applying to all nuclear power plants). They may also be written to apply only to a particular facility and would therefore appear as a part of a facility-specific operating license or permit. For example, the Commission of European Communities (CEC) favors facility-specific effluent controls rather than standard uniform emission standards (Gouvras et al. 1988). When the CEC exercises facility-specific type of control, it is usually established as total activity limits over time.

An additional factor governing releases of tritium to the environment involves making the radiation dose or activity level discharge ALARA. Technical and economic feasibility, as well as background radiation levels, are factored into this concept. Even when an upper activity limit for discharge is established, a facility may be required to not only stay below that limit, but to achieve even lower release levels to the extent that the balance between cost and benefit can be optimized.

\subsection{U.S. TRITIUM DISCHARGE LIMITS}

The air and liquid emissions from commercial nuclear power plants in the U.S. are governed by many federal and state regulations. Only those that apply to liquid discharges are discussed below. Table 5-1 presents the general dose and activity regulatory standards for water discharges. 
Table 5-1. United States Regulatory Limits on Radioactive Exposure to the Public and Release of Tritium.

\begin{tabular}{|c|c|}
\hline Regulation/Agency & $\begin{array}{c}\text { Radiation (1) dose or activity concentration } \\
\text { in water }\end{array}$ \\
\hline 10 CFR Part 20 (NRC) & $1.0 \times 10^{-3} \mu \mathrm{Ci} / \mathrm{mL}\left(10^{6} \rho \mathrm{Ci}\right)$ (tritium) \\
\hline 10 CFR Part 50 (NRC) & $5 \mathrm{mrem} /$ year (total body or any organ) \\
\hline 40 CFR Part 141 (EPA) & $\begin{array}{l}4 \mathrm{mrem} / \text { year (beta emitters) (total body } \\
\text { or any organ)(2) }\end{array}$ \\
\hline $\begin{array}{l}\text { WAC 173-200 (Washington } \\
\text { State) }\end{array}$ & $20,000 \rho \mathrm{Ci} / \mathrm{L}$ (tritium) \\
\hline 40 C.FR Part 190 (EPA) & $25 \mathrm{mrem} /$ year (total body or any organ) \\
\hline
\end{tabular}

NRC = Nuclear Regulatory Commission

(1) These dose limits are for exposure to the general public and are not occupational exposure limits.

(2) EPA estimates that $20,000 \rho \mathrm{Ci} / \mathrm{L}$ of tritium results in a total body or organ dose of $4 \mathrm{mrem} / \mathrm{year}$.

\subsubsection{CFR \$20, Standards for Protection Against Radiation}

The Nuclear Regulatory Commission (NRC) regulations set $1 \times 10^{-3} \mu \mathrm{Ci} / \mathrm{mL}$ $\left(10^{6} \rho \mathrm{C} i / L\right)$ as the effluent limit for tritium in water.

\subsubsection{CFR \$50, Appendix I, Design Requirements for Nuclear Reactors}

Appendix I of 10 CFR $\$ 50$ states that the annual radiation levels in liquid effluents from all nuclear reactors within a facility should not result in a dose or dose commitment of greater than $5 \mathrm{mrem} /$ year to the total body or to any organ of the body.

Under the regulation, facility operators must determine that the level of activity in the liquid effluent will not exceed the established dose limit. This is done by calculating an estimated emission level based on standard assumptions regarding population and exposure pathways. The limits are included in the technical specification for each plant, specifically in its offsite Dose Calculation Manual.

\subsubsection{CFR \$141, National Primary Drinking Water Regulations and Chapter 173-200 Washington Administrative Code (WAC), Water Quality Standards for Groundwater of the State of Washington}

The Code of Federal Regulations, 40 CFR \$141.16, sets forth the interim contaminant levels for beta particle emitters in drinking water. It states that "The average concentration of beta particle and photon radioactivity from manmade radionuclides in drinking water shall not produce an annual dose equivalent to the total body or any internal organ greater than $4 \mathrm{mrem} /$ year." 
Tritium and strontium-90 are set aside and given a limit for the "average annual concentration assumed to produce a total body or organ dose of 4 millirem." For tritium, that concentration 1 imit was set at $20,000 \rho \mathrm{Ci} / \mathrm{L}$.

Chapter 173-200 Washington Administrative Code (WAC), Water Quality Standards for Groundwaters of the State of Washington contains the criteria for ambient groundwater quality developed by the Washington State Department of Ecology (Ecology). The activity level for tritium is $20,000 \rho \mathrm{Ci} / \mathrm{L}$, the same as the EPA interim primary Drinking Water Standard.

Permanent standards for drinking water have been proposed and published in the Federal Register (July 18, 1991; Vol. 56, No. 138, pp 33050-33127). The proposed new contaminant level for beta and photon emitter activity remains at $4 \mathrm{mrem} /$ year, but a recalculation of the tritium dosimetry equation increases the concentration level for tritium to $60,900 \rho \mathrm{Ci} / \mathrm{L}$. Three years have passed since these proposed standards were published, and the rule has not yet been finalized. Therefore, it is uncertain if final adoption will include these increased levels for tritium.

\subsubsection{CFR $\$ 190$, Environmental Radiation Protection Standards for Nuclear Power Plant Operations}

The annual dose limits given in Table 5-1 above apply to total emissions, including both air and water discharges.

\subsection{RADIATION DOSE AND TRITIUM DISCHARGE LIMITS FOR OTHER COUNTRIES}

For the countries in Europe, a common framework for regulation is provided in Chapter III of the Treaty establishing the European Atomic Energy Community. In addition, all countries listed (except the former Soviet Union) are member states of the Organization for Economic Cooperation and Development and the Nuclear Energy Agency. These bodies provide overarching policy for limiting radiation exposure to the public. However, the procedures and methods for limiting the discharges vary from country to country (Gouvras et al. 1988). These variations depend on whether radiation control is enforced facility by facility or established by general numerical limits set for a geographical area or political jurisdiction.

In most countries, the procedure for licensing a facility and setting discharge limits begins with proposed discharge limits based on historical performance of similar facilities. To apply for regulatory authorization, the operator must show that the predicted discharge levels from the proposed facility would result in radiation doses below the regulatory dose limits. As part of the process of plant approval, the licensing authority conducts its own evaluation of the proposed discharge levels. They examine the proposed plant design, assess the "radiological capacity" of the receiving environment, and account for releases from other existing or planned facilities into the same environment (Gouvras et al. 1988).

The most important advisory body for international radiation protection is the International Commission on Radiological Protection (ICRP). This organization is a body of recognized experts from various countries and not a 
regulatory agency. Although the ICRP recommendations do not carry the force of law, they serve as a basis for most of the radiation protection standards and permit limits established by regulatory bodies throughout the world.

The 1990 ICRP recommendations set forth a proposed public dose limit for all radiation of one millisievert per year (mSv/year) (100 mrem/year). This limit includes the qualification that a higher value of effective dose could be allowed in a single year, if the average over 5 years does not exceed $1 \mathrm{mSv} /$ year (ICRP 199la).

\subsubsection{United Kingdom (UK)}

Legislation in the UK requires that all discharges of radioactive materials to the environment be authorized by the appropriate government department. All facilities must either use best practicable means to limit the discharges, or to certify that discharges are as low as reasonably practicable. The public dose limit for all radiation is $0.5 \mathrm{mSv} /$ year or 50 mrem/year (Bell et al. 1992).

Nuclear plants coming on line in the late 1980s in the UK were required to operate under site-specific numerical discharge limits. At the same time, established plants were being converted to this system (Gouvras et al. 1988).

In the fusion reactor area, the Joint European Torus tritium handling facility in the UK had applied for approval to discharge small amounts of tritium to the air and water, showing in its modeling that the release will lead to a collective dose of $0.23 \mathrm{~Sv} /$ year ( $23 \mathrm{mrem} / \mathrm{year}$ ).

\subsubsection{France}

In France, if the average activity concentrations in air and water at defined distances from a nuclear plant are lower than the established limits, then those emissions are assumed to be in compliance with individual dose limits set for the public (Gouvras et al. 1988). An administrative order establishing the conditions and limits of liquid radioactive effluents from the fuel disposal unit of the Creys-Maiville nuclear power plant sets the tritium limit at $15 \mathrm{TBq} /$ year (400 Ci/year) (APEC 1989).

\subsubsection{Germany}

Regulation to control radiation releases in Germany sets primary dose limits for tritium exposure. For members of the public, the dose is $0.3 \mathrm{mSv} /$ year (30 mrem/year) (Fiege 1992). The activity limits for nuclear facilities are derived from the dose limit by calculations established in the regulations.

A report on tritium published by the Karlsruhe Nuclear Research Center in Germany (Fiege 1992) provides normalized averages for tritium releases to air and water from German nuclear power plants. The amounts released are, as a rule, significantly below permitted activity levels. 


\subsubsection{Canada}

Liquid discharge of tritiated water in Canada is regulated by Health Canada. The present limit for tritium is $40,000 \mathrm{~Bq} / \mathrm{L}(1,080,000 \rho \mathrm{Ci} / \mathrm{L})$. This may be reduced to $7,000 \mathrm{~Bq} / \mathrm{L}(190,000 \mathrm{pCi} / \mathrm{L})$.

\subsubsection{Russia}

No information was available regarding radiation dose or tritium discharge limits for Russia.

\subsubsection{Japan}

No information for Japan limits was available when this section was prepared. 1 
DOE/RL-94-77

This page intentionally left blank. 


\subsection{TRITIUM SEPARATION TECHNOLOGIES}

In the past, tritium that was a normal byproduct of nuclear process operations has been discharged into the soil and surface waters or accumulated in stored waste and surface impoundments. Very little, if any, research on tritium separation has been exclusively dedicated to finding an economical method to mitigate low levels of tritium in aqueous effluent streams associated with nuclear processes. This is because present separation technologies are designed for "process" tritium. Process tritium is highly concentrated tritium or tritium oxide that is made as a product or separated from highly concentrated feed stream. "Environmental" tritium in contrast to "process" tritium is characterized by low concentration levels and potentially high feed volumes.

Although present separation technologies are effective for feeds containing high levels of tritium, their potential for removing environmental tritium from aqueous streams has been described as "too costly," "inappropriate," and "unworkable" for the reasons discussed below. A detailed Westinghouse Hanford Company (WHC) report (Waters 1988) discusses four specific technologies for tritium removal. It also analyzes al ternatives for environmental disposal of tritiated wastewater. Two other studies, commissioned by DOE, reach the same conclusions (King et al. 1991 and Nixon et a). 1991). These conclusions are discussed in the following section.

\subsection{HYDROGEN ISOTOPE SEPARATION}

Historically, the development of technology for separating hydrogen isotopes parallels the development of nuclear power for both domestic and strategic uses. Initially, a means to separate hydrogen and deuterium was developed to produce heavy water $\left(\mathrm{O}_{2} \mathrm{O}\right)$ for use as a neutron moderator and coolant in nuclear reactors. Further refinements of this technology were then developed to provide a method to remove the tritium that builds up in the $D_{2} 0$ moderator during heavy water reactor operation. Additionally, the strategic need for tritium resulted in processes for producing and purifying tritium. Finally, the potential use of tritium in fusion reactors continues to drive the search for a more cost-effective separation technology for hydrogen isotopes.

\subsubsection{Enrichment Technology}

Normally, isotopic separations employ small differences in atomic mass of isotopes within an elemental family to achieve a "physical" separation. Molecular mobility and vapor pressure are two physical properties that can be used as a basis for this kind of physical isotopic separation. The separation of uranium isotopes by the gaseous diffusion of UF 6 is an example of a physical process that separates isotopes based on differing molecular mobilities.

A cursory examination of the ratios of the atomic weights $(1: 2: 3)$ of the hydrogen isotopes, would lead one to think that the separation of hydrogen, deuterium, and tritium would be quite simple. However, physical separation is 
complicated by the presence of mixed chemical species, such as HD, HT, and DT or HDO, HTO, and DTO. Even with the presence of mixed isotopic molecules and the dilution effect introduced by the presence of oxygen when tritium is in the water form, mass differences are still sufficiently large to allow reasonable separations. Physical processes, with low unit separation efficiencies, such as water distillation, cryogenic hydrogen distillation, ultracentrifugation, or thermal hydrogen diffusion, have been used for hydrogen isotope separation.

In the case of combined hydrogen, the difference in atomic size and mass of the hydrogen isotopes induces differences in bond strengths (technically referred to as the "zero point energy"). Differences in bond strength can then provide a basis for isotopic separations when hydrogen is combined with another element. These chemical differences give rise to substantially different chemical reactivities for compounds containing hydrogen isotopes bonded in the same way. The exploitation of these differences to achieve an isotopic separation is a chemical process. Water electrolysis and exchange of elemental hydrogen with bound hydrogen are examples of chemical isotopic separation processes.

No single unit process step by itself is capable of making isotopic separations that would result in an isotopically pure product. To effect a suitable separation, an isotopic enrichment plant is usually constructed by interconnecting several process stages or cells. In the process, an enriched stream passes from cell to cell increasing in isotopic concentration after each stage. The depleted stream is looped back into a prior cell for continued enrichment. Because of the multiplicity of feedback loops, the first or lowest stage in the sequence must be the largest to accommodate the larger volume of flow. Each subsequent stage becomes successively smaller in capacity. Earlier stages may be a single large unit or a rank consisting of smaller cells. Such a plant design for isotopic separation is called a "cascade." The mathematics for design and operation of a separation cascade have been well developed and reported (Villani 1979).

For a single stage in a cascade process, the ratio of relative isotopic concentrations in the enriched stream exiting a cell to the relative isotopic concentrations of the recycled depleted stream is called the separation factor. For an enrichment plant, the ratio of isotopic concentrations in the enriched product stream to the depleted stream is the enrichment factor for the total process.

The lower the separation factor, the lower the efficiency of separation; therefore, more stages are required to achieve total enrichment. Conversely, a process with a higher separation factor is more efficient and requires fewer stages for a total separation of isotopes. Because each successive processing stage is a more complex rank of cells, a separation plant's size grows somewhat geometrically as the number of stages increases numerically (see Figure 6-1). Some processes, such as distillation or hydrogen exchange, may be designed to run in a column, as opposed to the pyramidal cell structure in a cascade.

In almost all separation schemes for hydrogen isotopes, the heavier isotope (tritium) normally remains in an enriched liquid phase or lower processing stage. Lighter isotopes normally flow out or up in a depleted 
Figure 6-1. Conceptual Tritium Separations Cascade System.

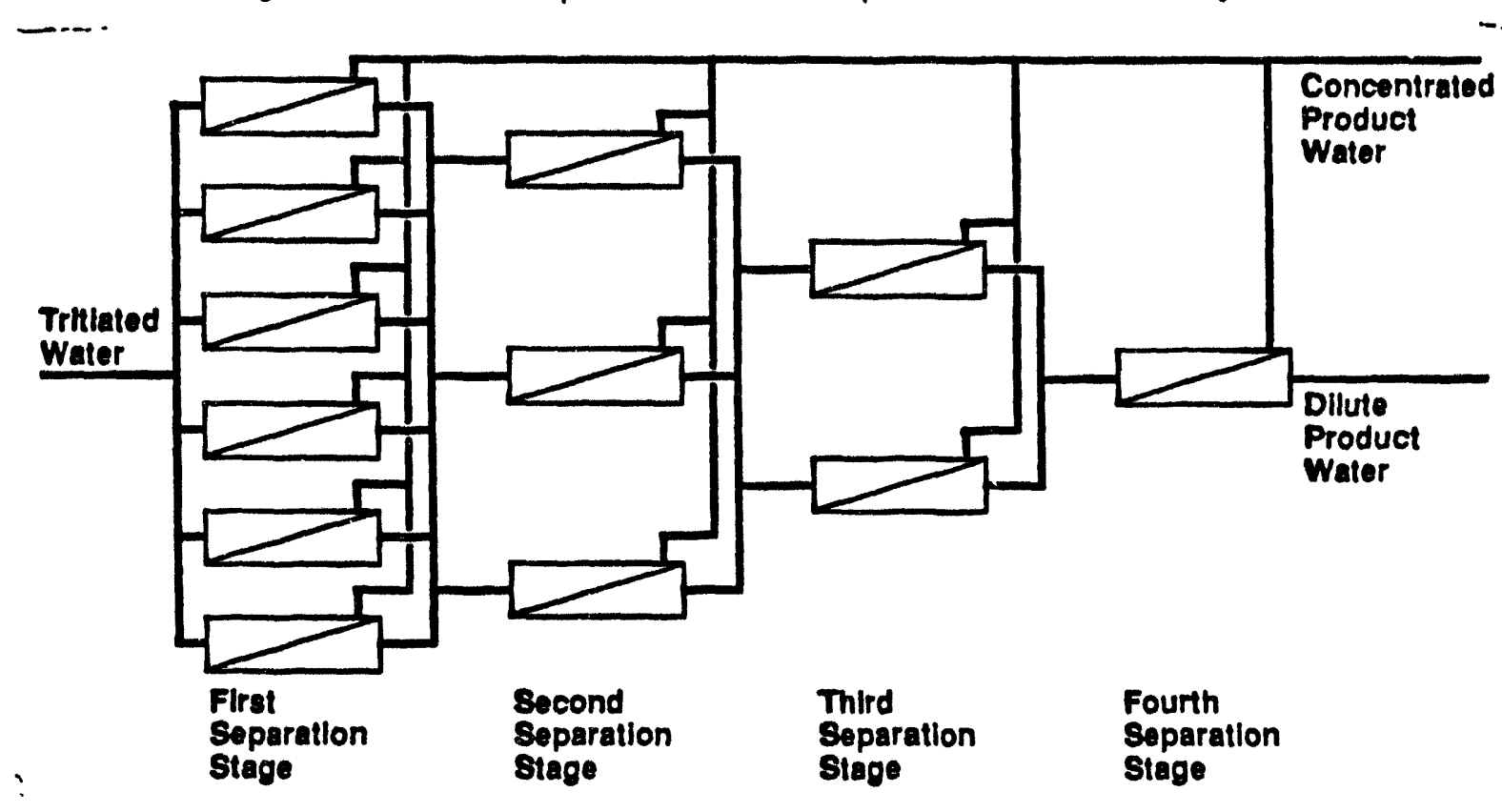

M2407021.1 
Table 6-1. Total Separation of Each Processing Stage.

\begin{tabular}{|c|c|c|c|c|c|c|c|c|c|}
\hline stage & 1 & 2 & 3 & 4 & 5 & 6 & 7 & 8 & 9 \\
\hline $\begin{array}{c}\text { Separation } \\
\text { factor }\end{array}$ & $4: 1$ & $4: 1$ & $4: 1$ & $4: 1$ & $4: 1$ & $4: 1$ & $4: 1$ & $4: 1$ & $4: 1$ \\
\hline Total separation & $4: 1$ & $16: 1$ & $64: 1$ & $256: 1$ & $1,024: 1$ & $4,096: 1$ & $16,384: 1$ & $65,536: 1$ & $262,144: 1$ \\
\hline
\end{tabular}

stream. This is a complicating factor in mitigating environmental tritium because the separation plant must completely process large volumes of feed to remove a small, more concentrated stream of tritiated waste.

\subsubsection{Physical Processes}

Physical processes for isotopic separation, such as distillation and diffusion, are characterized by low unit separation factors (1.05 to 1.8) (Vasaru 1993). A process, such as water distillation, with a separation factor of 1.05 , would require 120 stages to reduce tritium from $6,000,000$ $\rho C i / L$ to $20,000 \rho C i / L$. A distillation plant sized to accommodate a processing rate of 100 to $500 \mathrm{~L} /$ minute would cost hundreds of millions of dollars because of the high volume of process flow and because of the large number of stages required.

Although unit operating costs for physical separation processes can be relatively low, the capital cost for a plant using multiple stages of physical separation is exceedingly high. Because of the high numbers of separation stages required, no physical process would be appropriate for the treatment of tritiated water at the Hanford Site.

\subsubsection{Chemical Processes}

Chemical isotopic separation processes are based on an operation in which a chemical change is required to accomplish the separation. Chemical separations can have much larger separation factors ( 3 to 10 typically, but the separation factor for the Laser Exitation process is reported to be 10,000) (Vasaru 1993). A single stage for a chemical-based separation process can cost about the same as a stage for physical separation, but because a chemical process is now involved, operating costs per stage are likely to be much higher. Because fewer stages would be required for a chemical separating plant, construction costs can be less compared to a physical separation plant. A recent publication describes the tritium enrichment processes (Vasaru 1993).

6.1.3.1 Electrolysis. The electrolysis process, with a unit separation factor of 10, would appear to offer a reasonable opportunity for cost-efficient separation of tritium. An electrolysis plant, however, would require 6 stages to achieve separation of environmental tritium from wastewater. Each stage of the process requires complete conversion of water to hydrogen and oxygen electrically. The enriched hydrogen stream must then be oxidized to reform the water that is required as an input to the following stage. 
Single stage electrolysis of water requires about $6 \mathrm{kWh} / \mathrm{L}$, assuming $100 \%$ efficiency. At a flow rate of $100 \mathrm{~L} / m$ inute, a six-stage electrolys is plant would require just over $200 \mathrm{MW}$ of power, not including other separation and operating costs. This power requirement would be $20 \%$ of the output of the Washington Public Supply System (Supply System) Plant No. II here at Richland. Electrolysis of a milition gallons of wastewater six times over to remove a few milligrams of tritium would be a very costly operation and is not deemed an appropriate option for removing tritium from wastewater at the Hanford Site.

6.1.3.2 Catalytic Exchange. Catalytic hydrogen exchange is a process that is carried out in a column. Elemental hydrogen exchanges in a catalyst bed between an upward moving stream of hydrogen and a counter current flow of water. The catalyzed exchange process traps the heavier isotopes of hydrogen In the water phase. Except for the cost of preparing the hydrogen, operational costs for the exchange process are quite low. The major cost, however, is the capital required for a platinum catalyst bed of sufficient length and cross-section to accommodate the level of separation and volume of throughput required for the process.

\subsubsection{Combination Processes}

To offset a part of the more costly features of these separation schemes, commercial processes often link two technologies. The process for commercial separation of tritium from $\mathrm{D}_{2} \mathrm{O}$ that was developed by Atomic Energy of Canada Limited (AECL) uses a combined electrolysis and catalytic exchange process. The electrolysis step provides a stage of separation and produces hydrogen for the exchange step. Because of the addition of catalytic exchange, the electrical power required for this process would be about $9 \mathrm{kWh} / \mathrm{L}$. Again, at an operating rate of $100 \mathrm{~L}$ /minute, the power requirement would be just over 50 MW for electrolysis only. This reduces the power requirement substantially compared to the electrolysis-only process, but would still consume $5 \%$ of the Supply System Plant No. II output.

\subsubsection{Other Processes}

Multiphoton laser excitation is a relatively new technology for chemical separation that is still under development. The process operates by extracting tritium from water and is reported to have a separation factor of 10,000 . It would appear that with such a high separation factor, laser excitation could be considered a technology for tritium removal. However, laser operation is complex and capital intensive, and the exchange step is chemically complex. Because a significant portion of the hydrogen in the water to be cleaned up must be converted to trifluoromethane, the process is expensive to operate.

\subsection{POTENTIAL APPLICATION OF TRITIUN SEPARATION TECHNOLOGIES}

The reason isotopic enrichment technologies are not appropriate for separating tritium from liquid effluent because they are designed for processing a stream that contains tritium at a concentration of about $1 \mathrm{Ci} / \mathrm{L}$ $(100 \mu \mathrm{g} / \mathrm{L}$ of tritium). Environmental streams at the Hanford Site contain 
tritium levels that are 100,000 to $10,000,000$ times lower than this. Before treatment, these streams could al so contain dispersed solids, dissolved metals, and organics. It is assumed that before any attempt is made to remove tritium, it may be necessary to remove materials that might interfere with the process for separating tritium or would be required to be removed before final disposition of the stream.

Because presently available technologies are not economically feasible, and having all the background knowledge nresented above, it is possible to use the mathematics of cascade enrichment tlieory (Villani 1979) to speculatively design a hypothetical process to separate tritium.

It is highly probable that an appropriate process would be designed on membrane, liquid/liquid extraction, or ion exchange separation technology. Each separation methodology would be expected to have relatively low unit operating costs, require low to moderate capital input, and could have separation factors of 10 or higher. These technologies have been successfully employed in numerous commercial operations for separating a wide variety of chemical species. They also have good potential for continued technical growth and discovery, including the area of iritium separation.

A process with an actual unit separation factor as low as 3 could be used for tritium removal if both unit operating and capital costs were low. A plant designed on a separation factor of 3 would require about 13 stages and could process feeds containing 100,000 to $100,000,000 \rho \mathrm{Ci} / \mathrm{L}$ of tritium. The result of operation would be a treated stream with 10,000 to $20,000 \rho \mathrm{Ci} / \mathrm{L}$ level of tritium and a concentrated secondary waste containing 0.01 to $0.02 \mathrm{Ci} / \mathrm{L}$ tritium. In that process, a volume reduction of $2,000: 1$ would be achieved. A potential process with a separation factor as high as 8 would result in a plant having 7 separation stages.

When designing a plant, it is important to understand that the total separation required is not the difference between the tritium levels in the feed stream and the Drinking Water Standard $(20,000 \rho \mathrm{Ci} / \mathrm{L})$. The actual degree of separation is the ratio of the concentrations of tritium in the high-and low-level discharge streams from the separation plant (see Figure 6-2). 
Figure 6-2. Degree of Separation.

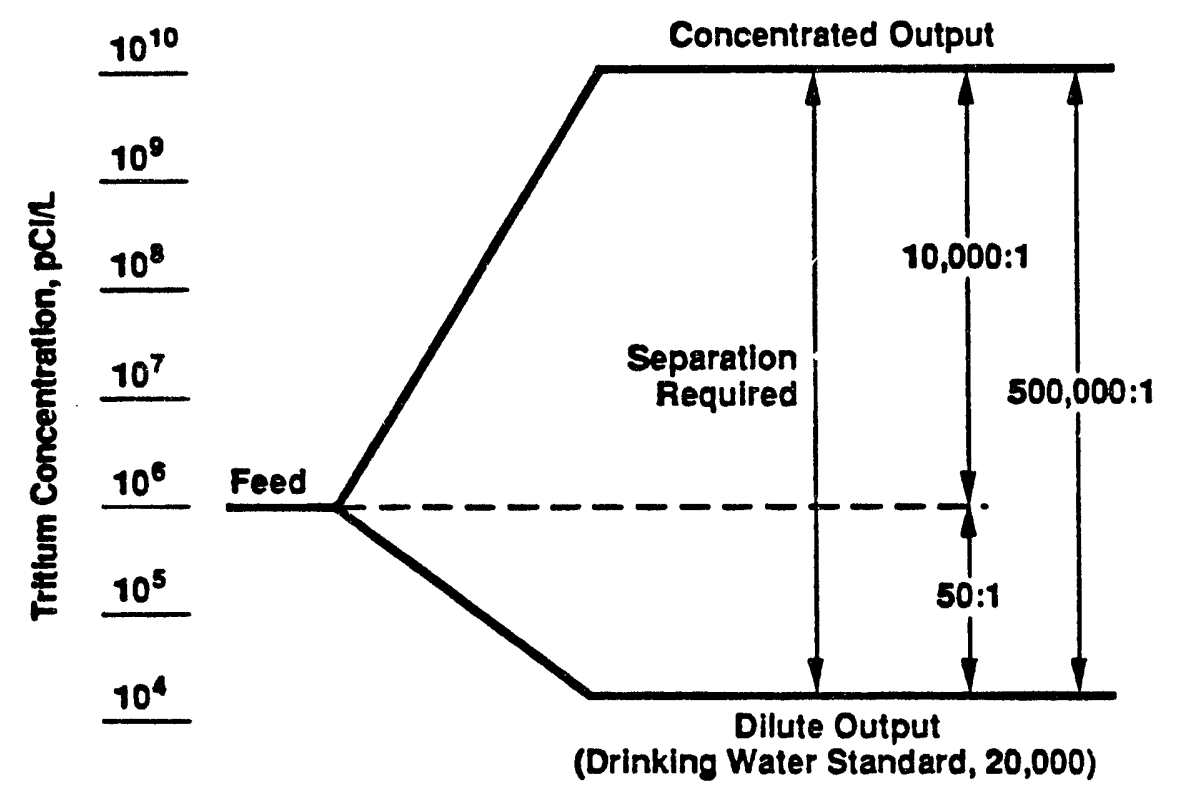

H9407017.2 
If the Drinking Water Standard for tritium were relaxed to $60,900 \rho \mathrm{Ci} / \mathrm{L}$ (see Section 5.3.3), it would reduce the cost of tritium removal. At a design separation factor of 3 , the number of stages would be reduced from 13 to 11 . If the design separation factor were as high as 8 , the stages would drop from 7 to 6 . Although these do not appear to be large changes, the impact is to eliminate the stage(s) that consist of the largest ranks of processing cells, thereby reducing the core of the processing plant by a much larger factor (see Figure 6-1).

Depending on the costs of disposition, the highly tritiated secondary waste stream from such a treatment plant could be appropriately treated for vaulted storage to allow the tritium to decay, or could be sent to a much smaller plant for further concentration and volume reduction. A second and much smaller plant would produce a tritiated waste stream at 10 to $50 \mathrm{Ci} / \mathrm{L}$ with a further volume reduction of $4,000: 1$. Total volume reduction for both plants in tandum would be $8,000,000: 1$. The low-level tritium stream from this plant would be cycled back into the feed to the first tritium removal plant.

\subsection{FUTURE DEVELOPMENT OF POTENTIALLY FEASIBLE SEPARATION TECHNOLOGY}

The possibility of building a plant as described above, depends upon the development of an approach that is a technical basis for the separation. The first results of such research is the report (Nelson et al. 1994) of a potential membrane separation technique by scientists at PNL. The researchers used a polyphosphazine membrane and tested a feed stream containing 20,000 $\rho \mathrm{Ci} / \mathrm{L}$ tritium. Tritium depletion as high as $74 \%$ was reported in one of the tests. The results of further testing in this area will be reported in subsequent years.

No other scientific reports on tritium separation were found; however, two other companies have shown interest in tritium separation, but it is not known if they are conducting any research at this cime. 


\subsection{TRITIUM AT THE HANFORD SITE}

\subsection{TRITIUM CONTAMINATION IN HANFORD SITE GROUNDWATER}

Reports on the environmental monitoring of the Hanford Site are issued each year. The Hanford Site Environmental Report 1992 (Woodruff and Hanf 1993) contains most of the information that is summarized and analyzed in this section. Additionally, specific reports on groundwater monitoring (Dresel et a1. 1993) and Columbia River monitoring (Dirkes 1993) are published by PNL. Each report includes data and discussion regarding the presence of tritium in the environment of the Hanford Site.

\subsubsection{Source of Tritium in Groundwater}

Past disposal practices at the 100 and 200 operating Areas at the Hanford Site have resulted in the discharge of more than 440 billion gallons of contaminated process water into the soil column. As a result, tritium concentrations greater than the $20,000 \rho \mathrm{Ci} / \mathrm{L}$ primary Drinking Water Standard are found in the groundwater within an area that encompasses almost $20 \%$ of the Hanford Site water table that is south of the Columbia River (see Figure 7-1).

With reactor and fuel processing operations shut down, soil discharge of tritiated wastewater has been discontinued. Atmospheric and ground releases of tritium from the Hanford Site were about $40 \mathrm{Ci}$ in 1992 (Woodruff and Hanf 1992). Subsurface migration of tritium-containing groundwater into the Columbia River is estimated to be 4,600 Ci for 1992 (Knepp 1994).

\subsubsection{East Area Tritium Plume}

The largest area of tritium contamination in groundwater exists within a 100 square-mile triangular-shaped plume that extends directly east and southeast toward the Columbia River from its apex at the source, the Plutonium-Uranium Extraction (PUREX) plant in the 200 East Area (see Figure 7-1). Tritium levels in monitoring wells near the PUREX facility are measured as high as $4,000,000 \rho \mathrm{Ci} / \mathrm{L}$. This high area of tritium concentration resulted from aqueous discharges from the PUREX plant during past operations from 1956 to 1989 . The aquifer in this area is fairly flat and porous allowing the plume to expand and migrate from its point of origin. The travel time from the source to the river along the shortest path is estimated to be 23 years (DOE 1987).

This plume merges with the Columbia River along a $30-\mathrm{km}$ distance north from the 300 Area. For $20 \mathrm{~km}$ of this distance, the tritium concentration at the river is greater than $20,000 \rho \mathrm{Ci} / \mathrm{L}$. For a short $2 \mathrm{~km}$ segment, the tritium concentration increases to greater than $200,000 \rho \mathrm{Ci} / \mathrm{L}$. No other ground contaminant from Hanford Site operations, except nitrate, has migrated this far from its source. 
Figure 7-1. Tritium $\left({ }^{3} \mathrm{H}\right)$ Concertrations in the Unconfined Aquifer, 1992.

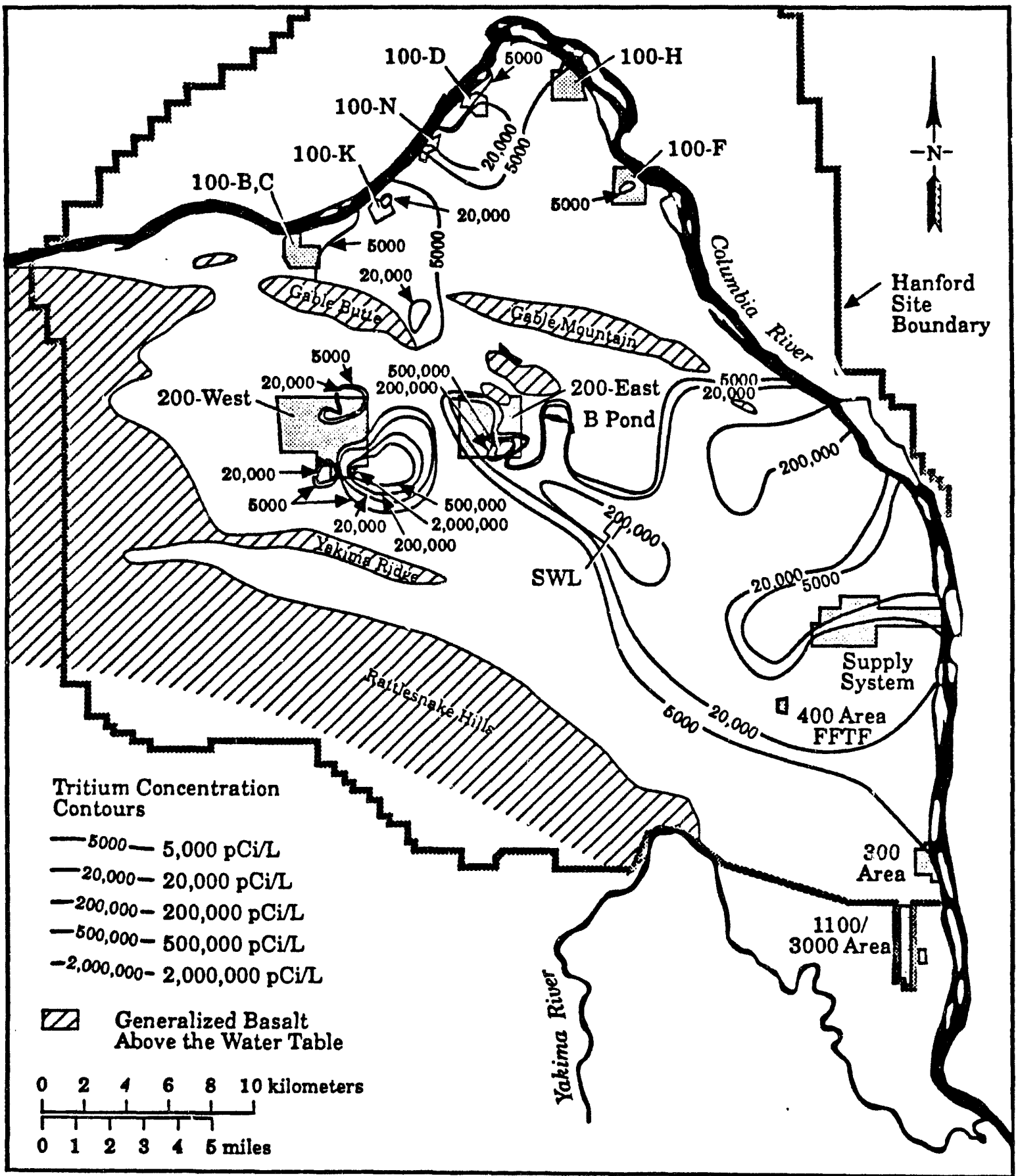




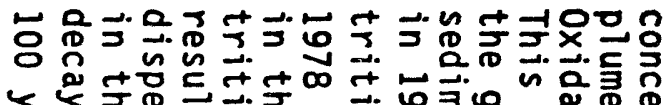

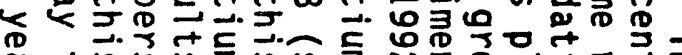

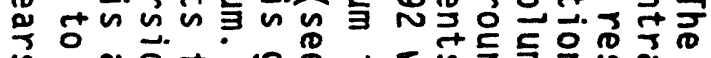

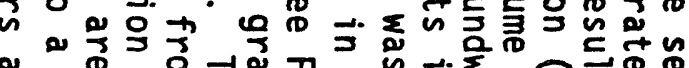

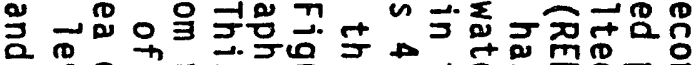

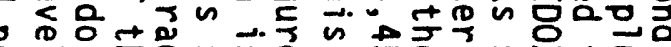

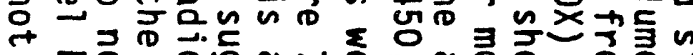

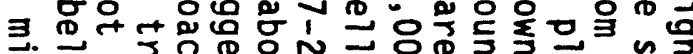

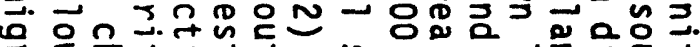

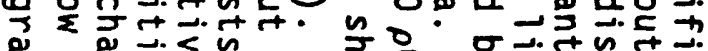

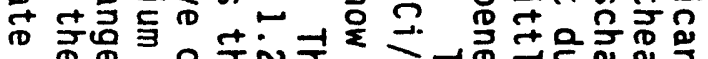

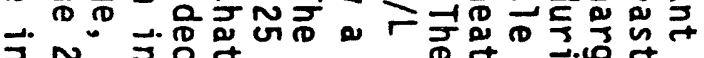

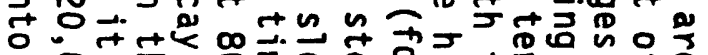
영-

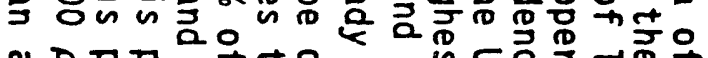

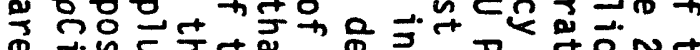

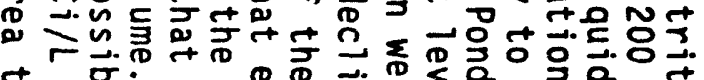

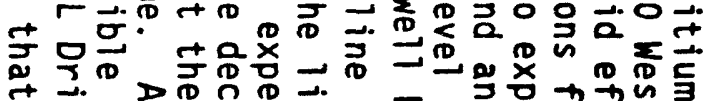

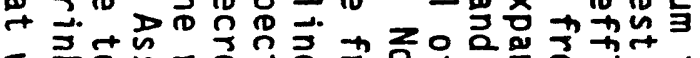

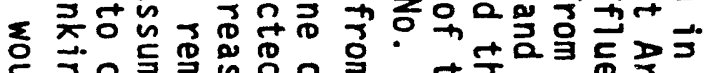

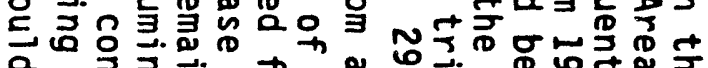

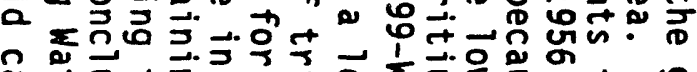

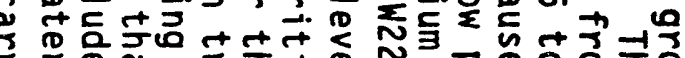

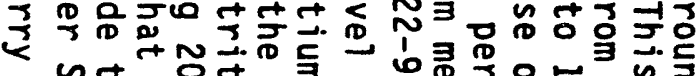

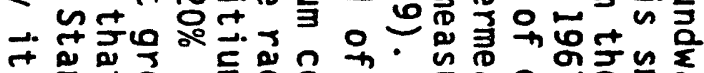

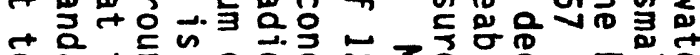

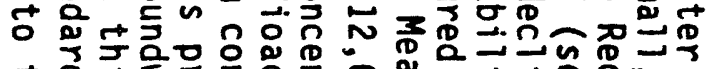

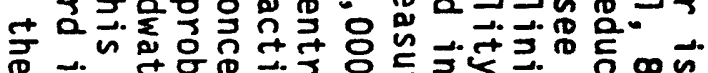

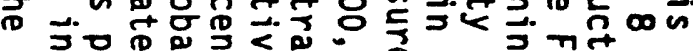

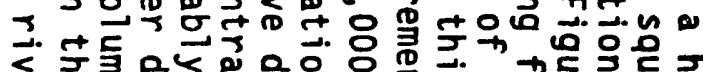

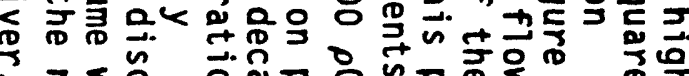

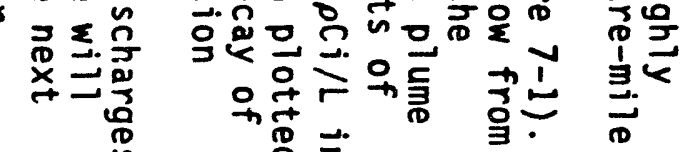

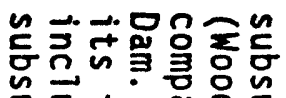

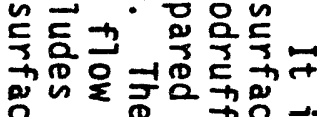
กิ सत कि

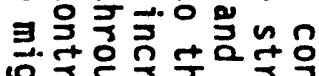

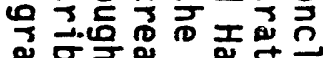

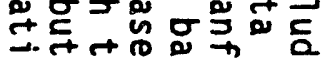

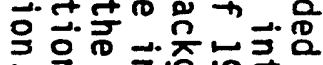
का

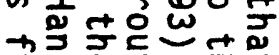

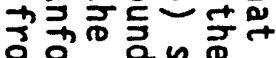
当옹문

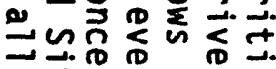

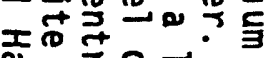

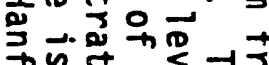

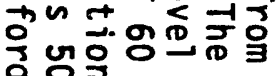

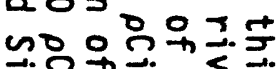

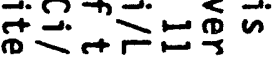

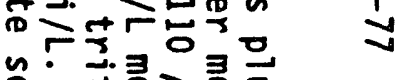

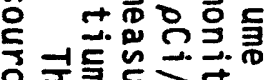

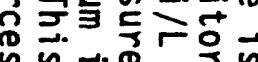

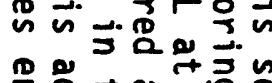

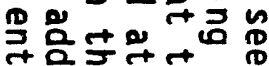

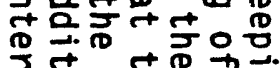

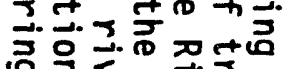

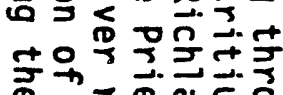

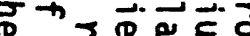

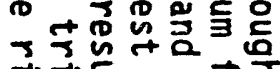

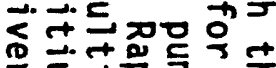

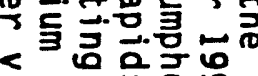
. 争旅 
Figure 7-2. Tritium Concentration Trend in Well 299-W22-9.

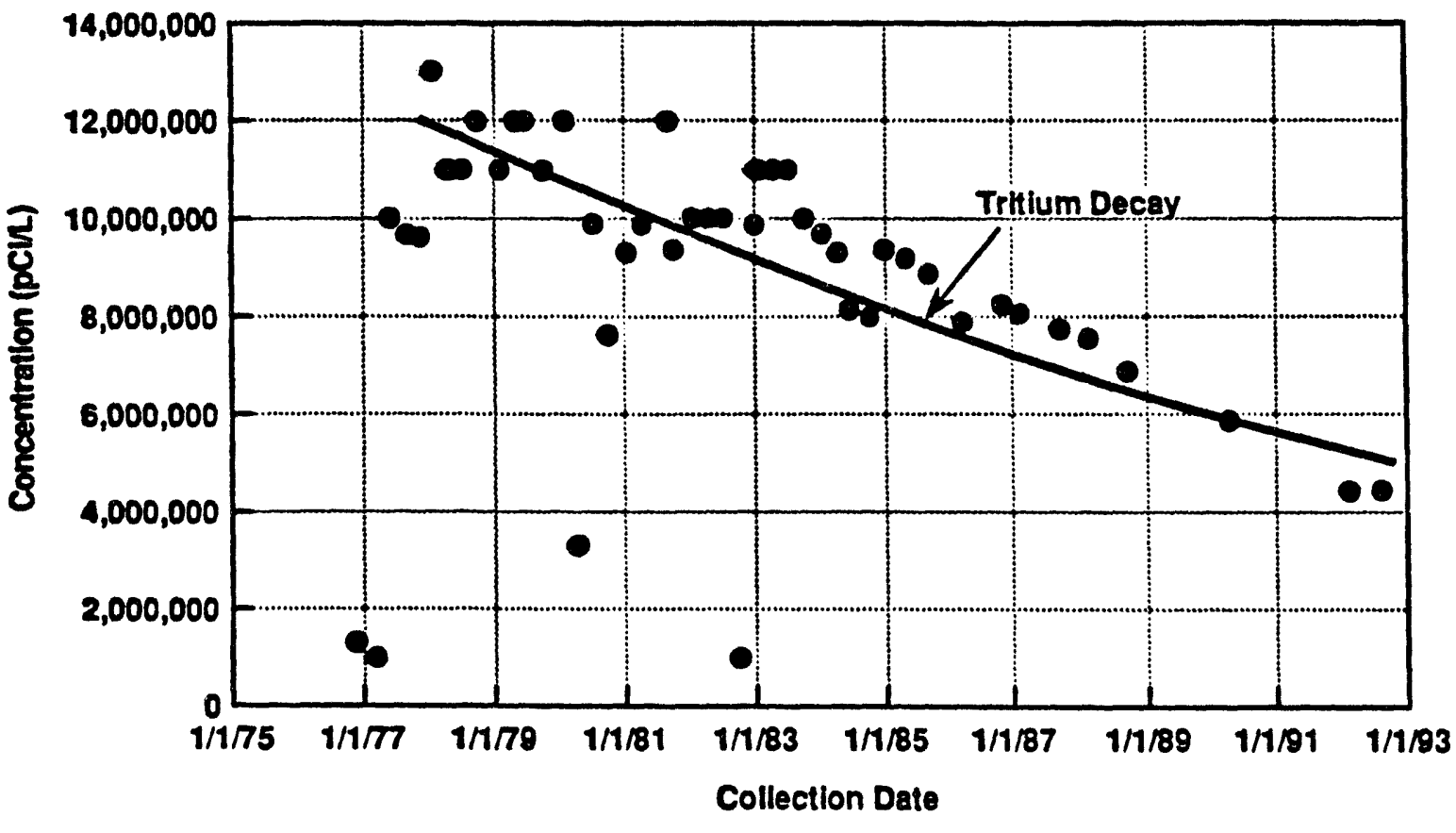

Mo407017.5 


\subsubsection{Surface Impoundments}

A concern at the 100 Area is the presence of high levels of tritium in the water in the $N$ and $K$ storage basins. Although not considered a part of the groundwater at the Hanford Site, these aging structures containing contaminated water present a potential for leakage or failure (Wittekind 1993).

The KE Basin contains $1,000,000$ gallons of water with a tritium concentration of $3,000,000 \rho \mathrm{Ci} / \mathrm{L}$. The $\mathrm{N}$ Basin is of similar volume, but contains tritium at levels up to $40,000,000 \mathrm{\rho Ci} / \mathrm{L}$. Potential treatment and disposition of the water in these basins is the subject of other Tri-Party Agreement Milestones.

\subsection{TREATMENT OF AQUEOUS WASTE CONTAINING LOW-LEVEL RADIATION}

When completed and in operation, the 200 Area Effluent Treatment Facility (ETF) will play a key role in the environmental cleanup of the Hanford Site. The 200 Area ETF, in combination with the 242-A Evaporator, will reduce the volume of liquid waste currently stored in double-shell (DST) and single-shell tanks (SST) and will provide a clean water effluent for discharge to the state-approved land disposal site (SALDS). The additional tank space is needed to support other site cleanup activities, such as surplus facility decontamination, waste retrieval from SSTs and DSTs, and waste vitrification. Although the ETF will remove radioactive contaminants, it is not capable of removing tritium (see Section 6.0).

\subsubsection{Area ETF Treatment Process}

The 200 Area ETF is a state-of-the-art wastewater treatment facility that has been designed to meet applicable regulations, including requirements of the EPA, Ecology, and DOE. The 200 Area ETF contains a series of process units or systems, which will reduce the concentration of organic contaminants by $95 \%$ and $w i 11$ reduce inorganic and radioactive contaminants (except tritium) by $99 \%$ from their original level in the wastewater feed. Ecology has determined that the piant design using these treatment systems is consistent with all known, available, and reasonable technology (AKART) and best available technology (BAT) for low-level aqueous waste stream processing. For a complete description of the plant and operations, see McDonald (1992).

The 200 Area ETF has been designed to treat 150 to $570 \mathrm{~L} /$ minute ( 40 to 150 gallons/minute) of wastewater. The feed stream to the 200 Area ETF comes either directly from the 242-A Evaporator or the Liquid Effluent Retention Facility (LERF) where it has been temporarily stored. The 200 Area ETF process design incorporates a flexible treatment system that can also treat wastewaters generated by future site remediation efforts.

For processing, the wastewater enters the primary treatment train where it is first filtered to remove suspended solids. Next, organic materials are destroyed, and finaliy inorganic and radioactive constituents, except tritium, are removed. The secondary waste from the primary treatment steps enters the secondary treatment train where excess water is removed by evaporation. 
Finally, the solids are dried and packaged for storage and/or disposal in an approved facility. Figure 7-3 shows a schematic diagram of the 200 Area ETF process.

The treated wastewater from the ETF will be discharged to an approved land disposal site. This site has been thoroughly studied and was selected to minimize any impact upon existing groundwater contamination and to maximize the radioactive decay of tritium during its possible underground migration to the Columbia River (see Section 7.3). Before discharge, the quality of the treated wastewater will be analyzed to verify that established discharge limits have been met.

\subsubsection{Composition of Permitted and Candidate Feed Streams}

Currently, the only regulated feed stream approved for treatment by the 200 Area ETF is the 242-A Evaporator process condensate. The 242-A Evaporator concentrates liquid DST and SST waste and returns the reduced volume of waste back to the DSTs. The byproduct from the 242-A Evaporator is a high volume, dilute wastewater that is transferred to the 200 Area ETF for treatment. The LERF basins will temporarily store the wastewater until the 200 Area ETF begins operating in 1995.

Although it can be technically defined as "distilled water," the process condensate still contains low levels of organic, inorganic, and radioactive impurities. Tritium, present as HTO in the 242-A Evaporator feed, is carried over with water vapor during evaporation and is transferred to the process condensate. Because HTO is not distinguishable from water during this evaporation step, tritium should be present in the condensate at the same concentration as it is in the feed. Tritium is diluted to a slightly lower concentration because condensate from the operation of vacuum steam jets in the evaporation plant is added to the process condensate as a part of the 242-A Evaporator process.

The analysis of 83 evaporator samples taken between 1977 and 1988 gave a maximum tritium concentration of $24,000,000 \rho \mathrm{Ci} / \mathrm{L}$. A statistical analysis of the tritium concentrations in all 83 samples gives $5,600,000 \rho \mathrm{Ci} / \mathrm{L}$ for the average tritium concentration and $6,300,000 \rho \mathrm{Ci} / \mathrm{L}$ for a $90 \%$ confidence level concentration (McDonald 1992).

Up to 20 other streams have been identified as candidates for processing at the 200 Area ETF. These include water from $K$ and $N$ Basins and water from any facility cleanout or groundwater pump-and-treat operation. Tritium is a contaminant in three of these streams. A comprehensive analysis of the process condensate is reported in McDonald (1992). 


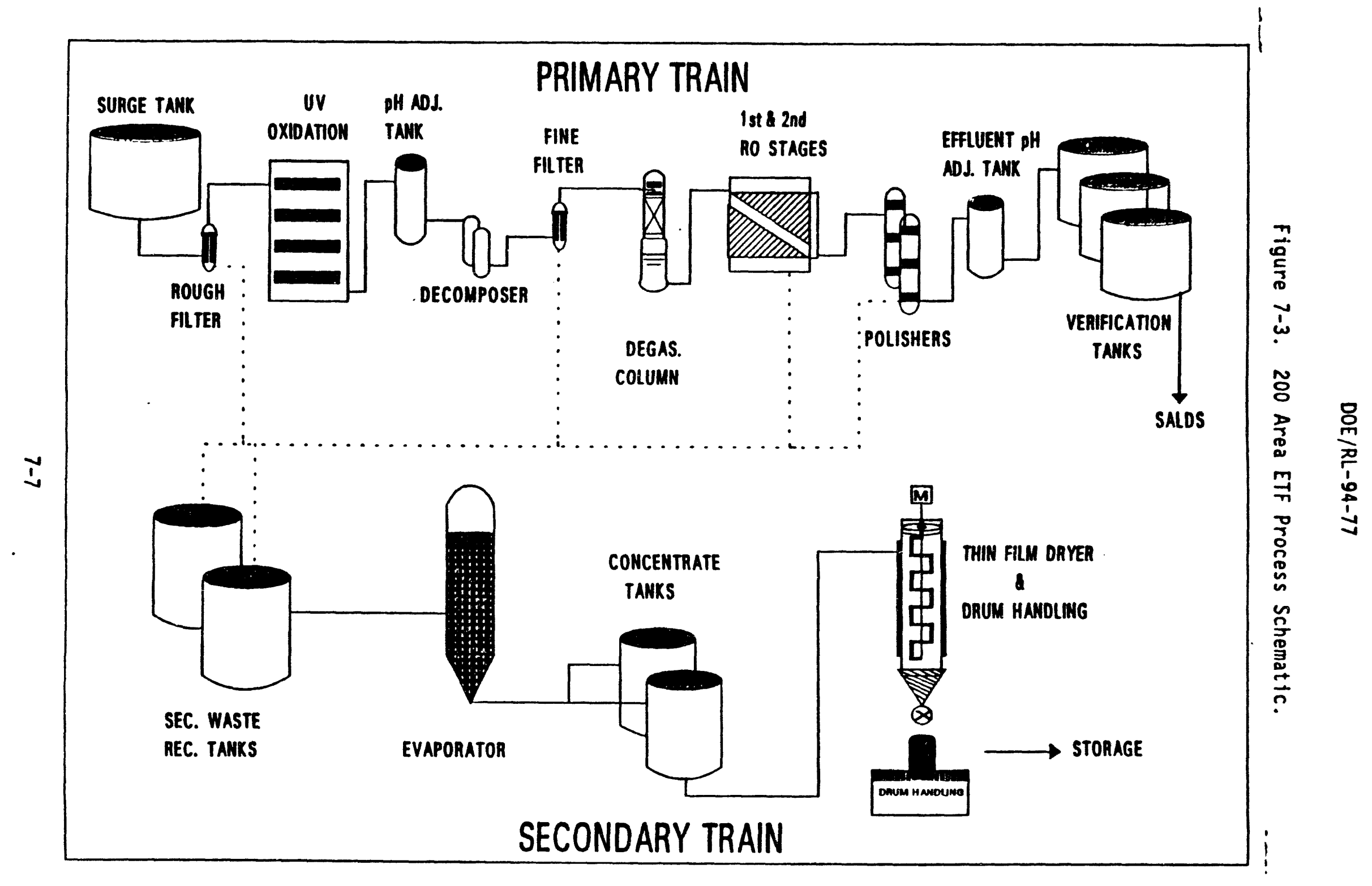




\subsubsection{Projected Discharge of Tritium}

Based on estimates of tritium contained in tank waste, the ETF during its operational life is expected to process 242-A Evaporator condensate containing $3,300 \mathrm{Ci}$ of tritium (SEPA 1993). This amount of tritium is estimated as of 1993 and not corrected for decay. Processing the wastewater from the $K$ and $N$ Basins would add about $10 \%$ to this total.

Although the processing capacity of the 200 Area ETF could be as high as $200,000,000 \mathrm{~L} /$ year, if it operates only on feed from the 242-A Evaporator, its annual output would more closely average $30,000,000 \mathrm{~L}$ of effluent. A total of $3,300 \mathrm{Cl}$ processed evenly over a 30 -year period would give an average tritium level of $3,700,000 \mathrm{\rho Ci} / \mathrm{L}$ in this volume of effluent, not anticipating tritium decay. Accounting for decay, the tritium concentration in the effluent in year 30 would average about $700,000 \mathrm{pCi} / \mathrm{L}$.

\subsubsection{Potential Reuse Options for Tritiated Mater at the Hanford Site}

Although options for reusing effluent from the 200 Area ETF are being seriously considered, it is important to understand that recycling does not mitigate the presence of tritium in treated effluent streams at the Hanford Site. Alternative uses for this resource will, however, conserve natural sources of water and reduce the ult imate volume of effluent discharged to the ground. Employing treated effluent as a final rinse for cleaning tanks, in facility decontamination or for soil washing will generate aqueous waste streams that will need to be processed and disposed to the ground when the cleanup and restoration process is completed. Tritium in the recycle stream will be carried through the candidate recyciing operation and will be contained in the aqueous waste presented for treatment and final ground disposal.

Recycling of effluent will require engineering means to supply the stream to the intended site in appropriate quantities and at the time needed. Using a LERF basin as lag storage for effluent intermittently produced by the ETF will help ensure constant supplies. Also, potential sites of reuse in general proximity to the pipeline carrying effluent from the ETF to the SALDS may be able to tap into the pipeline for supply.

\subsection{DISCHARGE OF TRITIATED HASTEWATER TO THE HANFORD SITE SOIL COLUMN}

Because there was no process to remove tritium from wastewater (see Section 6.0), an appropriate method for dealing with treated effluent containing low levels of tritium was needed. This was particularly critical at the Hanford Site because the 200 Area ETF is scheduled to start operations in mid-1995.

Several suggestions were offered that take advantage of the natural decay of tritium, $5.5 \%$ year. These suggestions proposed using a natural or engineered means to hold back the flow or discharge of tritiated water, allowing the tritium to decay to an acceptable level for ultimate flow or discharge into streams or rivers. 


\subsubsection{Disposal Options Considered in the Selection of Soll Column Disposal}

In a recent report, Ebasco (1993) developed an empirical ranking and evaluation of several proposed options for direct and delayed disposal of tritiated water. These alternative methods represent an array of choices, including ground discharge, slurry wall confinement, grout solidification, and evaporation. Because this study has not been officially published, its results are presented here in some detail.

Twenty-two alternatives for treating and/or disposing the wastewater were originally considered by Ebasco. These alternatives were compared against each other by assigning estimated costs and levels of associated risk. The risk factors assigned were an empirical estimate of the consequences of delayed schedules, adverse health effects to workers and the public, adverse ecologic impact, and failure to achieve desired technical performance or to satisfy regulations and other requirements.

Eleven alternatives were eliminated from further consideration in a process established to screen for excessive cost and high risk. The remaining alternatives were then scored according to relative cost and risk factors. In the scoring, a zero represents the lowest threshold of acceptability and a higher score in a range represents a lower cost or risk. The overall results of the evaluation are provided in Table 7-1, in descending order of score.

Subsurface disposal is the highest rated alternative, receiving the highest rating in four of the seven categories. It is consistent with the 200 Area ETF disposal to the soil column and poses relatively low risks to workers, the public, and the environment. Subsurface disposal is a proven technology that presents little risk of unexpected future liabilities.

Public participation was sought and received on this disposal method through the State Environmental Policy Act approval process. Although there is a degree of public sensitivity to the ground disposal method, it must be viewed differently from the historical perception of wastewater disposal at the Hanford Site. Past disposal practices resulted in contamination of the soil because historical wastewaters contained certain waste species that concentrated in the soil near the point of disposal. Because tritium does not concentrate during movement through the soil column as do metal ion contaminants, tritiated wastewater can be disposed to the ground with assurance that it will dilute and decay and not cause future contamination of the soil. 
Table 7-1. Results of Cost/Risk Evaluation.

\begin{tabular}{lc}
\hline \multicolumn{1}{c}{ Alternative } & Score \\
\hline Subsurface disposal & 8.4 \\
Delayed subsurface disposal & 8.0 \\
Slurry wall confinement & 7.5 \\
Ice confinement & 7.1 \\
Delayed river discharge & 7.1 \\
Disposal to pond & 6.8 \\
Grout solidification & 6.7 \\
Direct river discharge & 6.7 \\
Solar evaporation & 5.5 \\
Irrigation & 5.2 \\
Mechanical evaporation & 3.7 \\
\hline
\end{tabular}

\subsubsection{Groundwater Modeling Done to Support Selection of the Disposal Site}

To implement the strategy of ground disposal of tritiated effluent from the 200 Area ETF, a number of candidate locations at the Hanford Site were evaluated (Koegler 1992). A panel selected seven sites based on preliminary screening. Each site was then subjected to a thorough evaluation of several criteria considered important to the success of the project. From this evaluation, three sites were selected for more detailed characterization and groundwater modeling studies (Koegler 1990 and Golder 1990a). Figure 7-4 shows the geographical location of the three candidate sites.

Using a groundwater modeling computer package (Golder 1983), Golder Associates reported two groundwater modeling exercises (Golder 1990b and 1991). Particular emphasis of the modeling was focused on predicting the movement of tritium in effluent from the 200 Area ETF with each site as a location for discharge. The accumulation of the works by Golder, including the final modeling of solute transport and plume migration of tritium, provides a basis for understanding the movement of groundwater beneath the Hanford Site.

The report of the modeling of estimated travel times (Golder 1990b) defines the groundwater pathway from each candidate site to the Columbia River. Initial results of the modeling predict travel times that range from 20 to 134 years with an estimated standard error of $20 \%$.

A11 pathways except one, the one with the shortest migration time, proceed northward through Gable Gap, a relatively narrow passageway in the basalt formations below Gable Butte and Gable Mountain (see Figure 7-1). An examination of the groundwater table contours (Figure 7-5) from the modeling, 

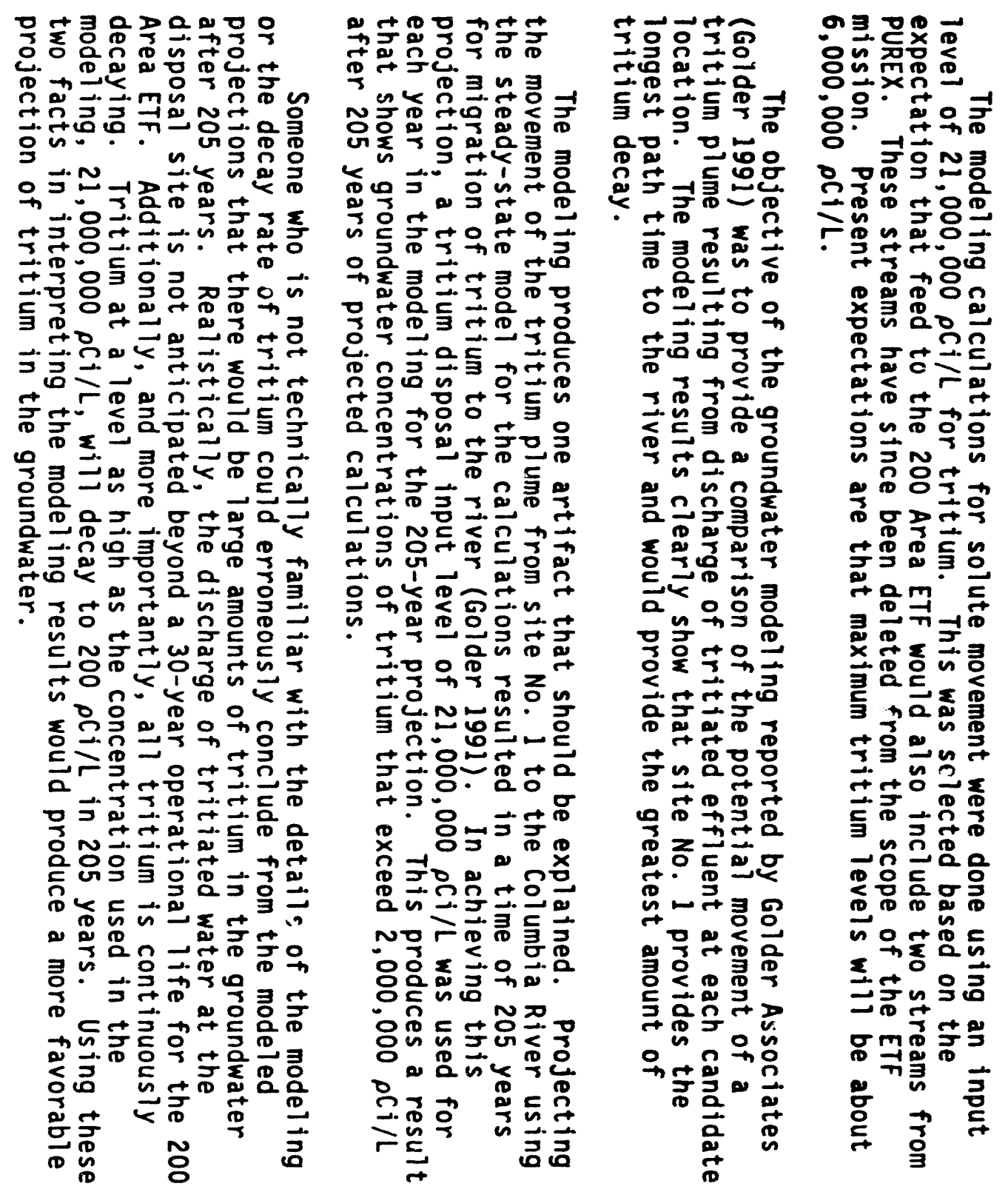

宁容㝘㟔
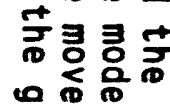

产率言

200

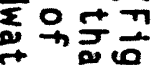

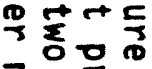

言웅ㄱ

承至气

옥号的。

宁守吉

要至的的

욱官嵒尔

人를

号言.

幽品

$\checkmark$ 
Figure 7-4. Location of Final Three Candidate Sites.

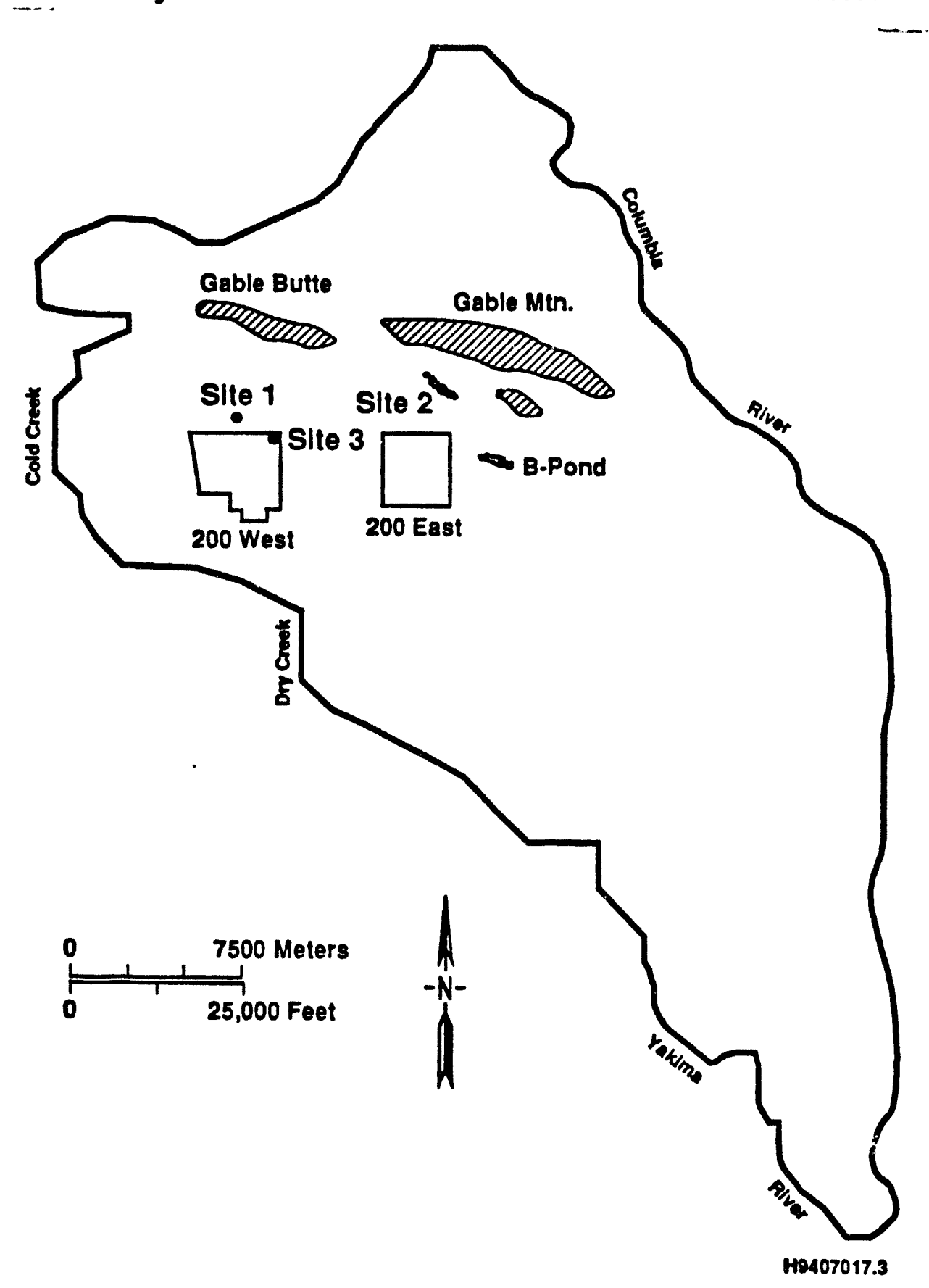


Figure 7-5. Simulated Hydraulic Head Contours with Disposal at the State-Approved Land Disposal Site (Golder 1991).

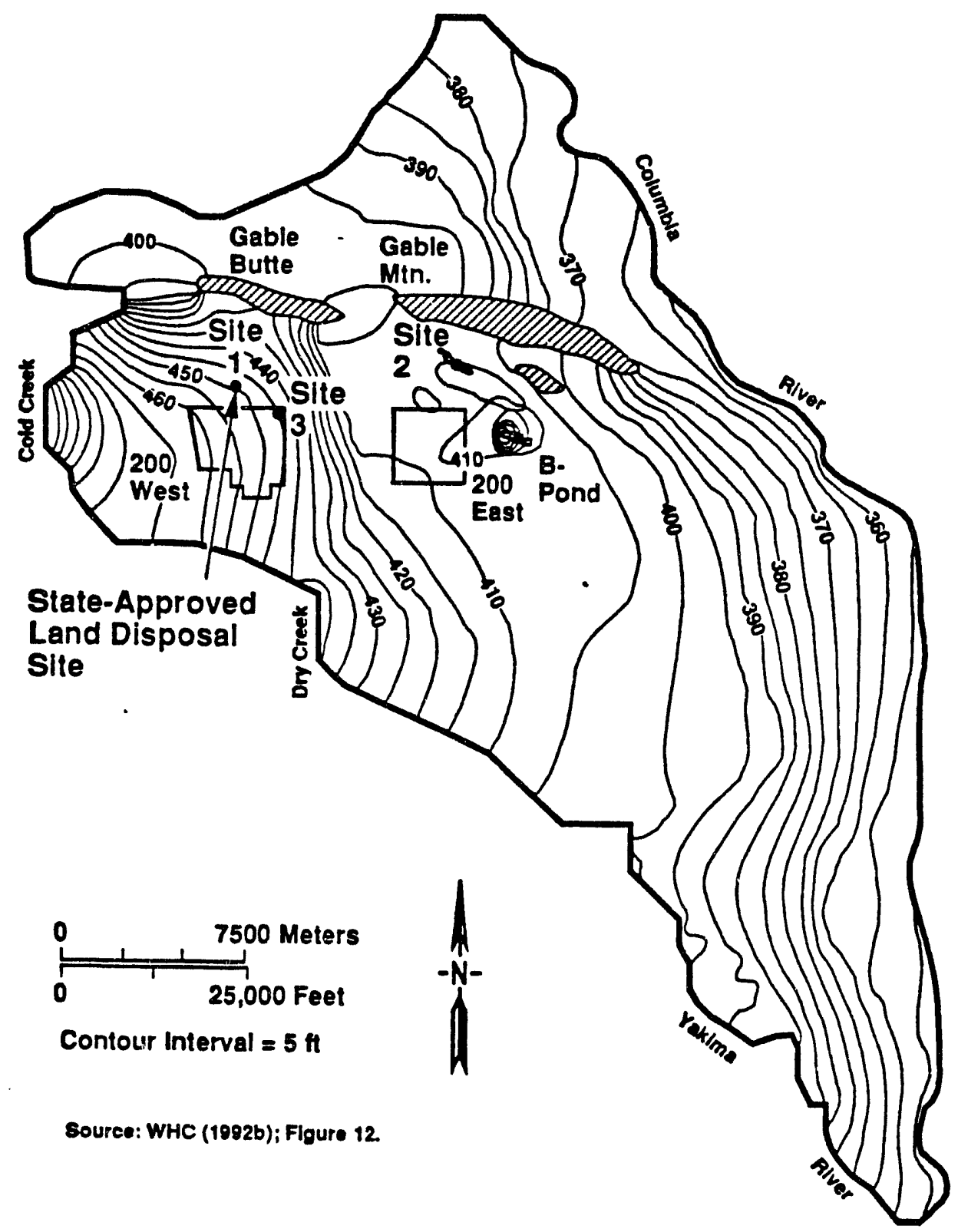

H9407017.4 
DOE/RL-94-77

This page intentionally left blank.

$7-14$ 


\subsection{TRITIUM AT THE SAVANNAH RIVER SITE}

Although a number of DOE sites have experienced tritium emissions and have areas of environmental tritium contamination, the Savannah River Site (SRS) has reported the most significant levels of tritium emissions (see Section 3.3.3, Table 3-3). Therefore, it is important for this report to examine the SRS operations regarding tritium.

\subsection{EXTENT OF THE TRITIUM CONTAMINATION AT SRS}

The Savannah River Site consists of a number of DOE nuclear facilities. These facilities include reactor operations, spent fuel processing, and tritium production. It is not surprising, therefore, that it has historically experienced the highest tritium emissions of any DOE location. It also has the highest levels of tritium in its groundwater. Since operations began, several million Ci of tritium containing waste have been placed in the SRS burial ground in packaged solid materials (DOE 1991).

The Savannah River Site Environmental Report for 1992 (Arnett 1993) reports tritium contamination in both surface and groundwater. Measured discharges of tritium to the Savannah River declined from $24,000 \mathrm{Ci}$ in 1986 to $14,000 \mathrm{C} i$ in 1992. Concentrations of tritium in tributaries to the Savannah River range from 40,000 to $240,000 \rho \mathrm{Ci} / \mathrm{L}$. Tritium in the Savannah River downstream from SRS in 1992 ranged from 1,000 to $4,000 \rho \mathrm{C} / \mathrm{L}$ compared to an upstream background measuring 100 to $200 \rho \mathrm{Ci} / \mathrm{L}$. Although this is still below the Drinking Water Standard, it is much higher than the $110 \rho \mathrm{Ci} / \mathrm{L}$ total tritium in the Columbia River down stream from Hanford Site operations (Dirkes 1993).

Tritium levels in surface and groundwater are extensively monitored and reported for SRS (Arnett 1993) just as they are for the Hanford Site (Woodruff and Hanf 1993). Seepage basins in the F and H Areas at SRS have associated underground tritium plumes with concentrations near the discharge source as high as 25,000,000 $\rho \mathrm{C} i / \mathrm{L}$. These tritium concentrations at SRS are much higher than those measured for present groundwater plumes at the Hanford Site.

The underground tritium plumes at SRS appear as fairly small localized areas in maps published in the report (Arnett 1993), but the lowest concentration gradient reported for the $\mathrm{H}$ Area plume is $40,000 \rho \mathrm{Ci} / \mathrm{L}$ and is $1,000,000 \rho \mathrm{Ci} / \mathrm{L}$ for the $\mathrm{F}$ Area. The scope of the groundwater contamination would appear much larger at SRS if tritium concentrations were reported down to $5,000 \rho \mathrm{Ci} / \mathrm{L}$ as is done at the Hanford Site.

The DOE-SR officials signed the Federal Facility Agreement (FFA) on January 15, 1993. The FFA, which sets the terms of environmental remediation at SRS, is an agreement between the South Carolina Department of Health and Environmental Control, the EPA, and DOE-SR.

Because of the concern about tritium in the environment in and near SRS, two committees have been formed to address these issues: (1) the Technical Advisory Committee for the evaluation of Trans-Savannah River Groundwater 
Flow; and (2) the Technical Advisory Committee for the Georgia Tritium Project (Arnett 1993). The activities of these committees will be monitored for information that would be appropriate for future reports.

\subsection{TRITIUH MANAGEMENT AT SRS}

At the SRS, an Effluent Treatment Facility (SRS-ETF) provides low-level liquid waste treatment of contaminated water that was generated in the $F$ and $H$ Areas and previously sent from operations to seepage basins. This plant, in operation since October 1988 (DOE 1991), like the 200 Area ETF presently under construction at the Hanford Site, provides filtration, reverse osmosis, and ion exchange equipment for processing liquid effluent. The water processed by the SRS-ETF consists of evaporator overheads from canyon and tank farm operations, contaminated cooling water, and stormwater runoff (Siler et al. 1991).

The SRS-ETF project does not provide any equipment or process for control or removal of tritium. Holding ponds for radionuclide decay and a final effluent evaporation step were proposed as alternatives for tritium management. Neither option was included in the final plan.

Effluent from the SRS-ETF is discharged directly into the Upper Three Runs Creek, which in turn flows into the Savannah River at the site boundary (DOE 1991). In 1992 the Savannah River received 2,400 Ci of tritium by direct discharge of tritiated effluent and $11,400 \mathrm{Ci}$ by groundwater migration from seepage basins. This total for SRS in $1992,13,800 \mathrm{Ci}$, is exactly three times the amount of tritium $(4,600 \mathrm{Ci})$ leaving the Hanford Site in the Columbia River in that same year (Knepp 1994).

Two studies concerning tritium management at SRS have been sponsored by the DOE. The first, reported by king et al. (1991), reviews the array of tritium enrichment methods reported similarly by Vasaru (1993) and discussed in Section 6.0 of this report. The authors conclude that a process combining electrolysis and bithermal catalytic exchange is the most promising option for tritium removal at SRS; however, there has been no further development of this technology.

A second report (Nixon et al. 1991) reviews the same set of technologies and concludes that "the use of tritium separation techniques to remediate tritiated groundwater at the SRS is not feasible." The authors recommend a process of pumping tritiated groundwater from critical areas and reinjecting it into an upgradient well allowing more time for the tritium to decay.

\subsection{PERMIT CONDITIONS FOR DISCHARGE OF TRITIATED WASTEWATER AT SRS}

The discharge of treated water from the SRS-ETF to a surface stream is subject to a National Pollution Discharge Elimination System (NPDES) permit approved by the South Carolina Department of Health and Environmental Control. The discharge criteria for process control includes an oil and grease limit (15 mg/L daily maximum), a Biochemical Oxygen Demand limit (40 mg/L daily maximum), and limits on all toxic metals (siler et al. 1991) 
According to regulatory sources at SRS (Todaro 1994), discharge of tritium in liquid effluent from the SRS-ETF is not controlled by the permit. The primary guideline for discharging tritium at SRS is the Derived Concentration Guide (DCG) of 2,000,000 $\rho \mathrm{Ci} / \mathrm{L}$.

The tritium in the treated effluent discharged from the SRS-ETF in 1993 averaged $7,440,000 \rho \mathrm{Ci} / \mathrm{L}$. This level of tritium discharge is allowable in South Carolina by applying the "mixing zone" concept. This regulatory concept permits the discharge from the SRS-ETF to be diluted in the stream before applying the primary Drinking Water Standard for tritium. These mixing zones are established at the point of discharge into the creek and at the point where the stream empties into the Savannah River. As long as the tritium level measured downstream from a mixing zone is less than the Drinking Water Standard, discharge is permitted. 
DOE/RL-94-77

This page intentionally left blank.

8-4 


\subsection{CONCLUSIONS}

Process technology for a number of hydrogen isotope separation methods was reviewed. All processes were developed for the separation of tritium from a concentrated low volume stream. The potential application of these processes to low-level tritium in large volumes of treated effluent or groundwater is projected to require high capital and operating costs.

In the absence of appropriate separation technology, effluent containing tritium is discharged into the ground, rivers, and oceans around the world. Discharge of tritiated waste effluent into the soil column has been approved at the Hanford Site (SEPA 1993). Residence time in the ground is sufficient for the tritium to decay to levels below the Drinking Water Standard. 
DOE/RL-94-77

This page intentionally left blank. 


\subsection{REFERENCES}

APEC, 1989, "Order of 29 September 1989 on Licensing the Release of Liquid Radioactive Effluents from the Fuel Disposal Unit of the Creys-Malville Nuclear Power Plant," in Journal Officiel de la Republique Francaise.

Arnett, M. W., L. K. Karapatkis, and A. R. Mamatey, 1993, Savannah River Site Environmental Report for 1992, Westinghouse Savannah River Company, Aiken, South Carolina.

Bell, A. C., P. Ballantyne, C. Caldwell-Nichols, and M. Wykes, 1992, "Routine Tritium Releases from JET," in Fusion Technology 21:506-511.

Beral, V., H. Inskip, P. Fraser, M. Booth, D. Coleman, and G. Rose, 1985, "Mortality of Employees of the United Kingdom Atomic Energy Authority," in British Medical Journal, 291:440-447 (cited in Okada 1993).

Beral, V., P. Fraser, L. Carpenter, M. Booth, A. Brown, and G. Rose, 1988, "Mortality of Employees of the Atomic Establishment," in British Medical Journa 7, 297:754-770 (cited in Okada 1993).

Dirkes, R. L., 1993, Columbia River Monitoring: Distribution of Tritium in Columbia River Water at the Richland Pumphouse, PNL-8513, Pacific Northwest Laboratory, Richland, Washington.

DOE, 1987, Plan and Schedule to Discontinue Disposal of Contaminated Liquids into the Soil Column at the Hanford Site, U.S. Department of Energy, Washington, D.C.

DOE, 1991, Report of the Task Group on Operation of Department of Energy Tritium Facilities, U.S. Department of Energy, Washington, D.C.

Dresse 1, P. E., D. R. Newcomer, J. C. Evans, W. D. Webber, F. A. Spane, Jr., R. G. Raymond, and B. E. Opitz, 1993, Hanford Site Ground-Water Monitoring for 1992, PNL-8716, Pacific Northwest Laboratory, Richland, Washington.

Ebasco, 1993, Evaluation of Alternatives for Processing and Disposing Wastewater Containing Tritium, Ebasco Environmental, a Division of Ebasco Services, Inc., Richland, Washington.

Fiege, A., 1992, Tritium, Karlsruhe Nuclear Research Center, Ltd., Karlsruhe, Germany, English Translation, PNL-TR-494.

Golder Associates, 1983, Groundwater Computer Package: User and Theory Manuals, Golder Associates, Inc., Redmond, Washington.

Golder Associates, 1990a, Travel Time Estimates for Alternative Crib Locations, Hanford Site, Washington, Golder Associates, Inc., Redmond, Washington, Published as an Appendix to Koegler 1990. 
Golder Associates, 1990b, Travel Time and Groundwater Mounding Estimates for Alternative Crib Locations, Hanford Site, Washington, Golder Associates, Inc., Redmond, Washington, Published as an Appendix to Law 1992a.

Golder Associates, 1991, Groundwater Monitoring and Plume Migration Analysis for Alternative Tritium Disposal Locations, Hanford Site, Washington, Golder Associates, Inc., Redmond, Washington, Published as an Appendix to Law $1992 b$.

Gouvras, G., F. Luykx, and P. I. Mitchell, 1988, "Review and Analysis of Discharge Limitation Practice in the European Community, " in Radiation Protection in Nuclear Energy, IAEA 1988, Vol. 2, Pp. 113-122.

IAEA, 1984, Management of Tritium at Nuclear Facilities, Technical Report Series No. 234, International Atomic Energy Agency, Vienna, Austria.

IAEA, 1991, "Safe Handling of Tritium: Review of Data and Experience," in Technical Report Series No. 324, International Atomic Energy Agency, Vienna, Austria.

ICRP, 1978, "Limits on Intakes of Radionuclides by Workers," in ICRP Publication 30, Part 1, Pergamon Press, International Commission on Radiological Protection, Oxford (cited in Okada 1993).

ICRP, 1991a, "1990 Recommendations of the International Commission on Radiological Protection," in Annals of the ICRP 21(1-3), ICRP Publication 60, Pergamon Press, International Commission on Radiological Protection, Oxford, England.

ICRP, 1991b, "Limits on Intakes of Radionuclides by Workers Based on 1990 Recommendations," in ICRP Publication 61, Pergamon Press, International Commission on Radiological Protection, Oxford, England (cited in Okada 1993).

Katz, J. J., 1978, "Deuterium and Tritium," in The Kirk-Othmer Encyclopedia of Chemical Technology, Third Edition, Vol. 3, John Wiley \& Sons, Inc., New York.

King, C. M., V. Van Brunt, R. B. King, and A. R. Garber, 1991, Concepts for Detritiation of Waste Liquids, WRSC-MS-91-027, Westinghouse Savannah River Company, Aiken, South Carolina.

Knepp, A. J., 1994, Hanford Site-Wide Groundwater Remediation Strategy, in preparation.

Koegler, K. J., 1990, Preliminary Site Evaluation Report for a Soil Column Discharge site for the 242-A Evaporator and Purex Plant Condensate Treatment Facility, WHC-SD-EN-EE-002, Westinghouse Hanford Company, Richland, Washington.

Koegler, K. J., 1992, Process for Selecting a Soil Column Disposal Site to Receive Treated Effluent Containing Tritium, WHC-SA-1456, Westinghouse Hanford Company, Richland, Washington. 
Law, A. G., 1992a, Travel Time and Groundwater Nounding Estimates for Alternative Crib Locations, Hanford Site, Washington, WHC-SD-EN-ES-021, Westinghouse Hanford Company, Richland, Washington.

Law, A. G., 1992b, Groundwater Nonitoring and Plume Migration Analysis for Alternative Tritium Disposal Locations, Hanford Site, Washington, WHC-SD-EN-ES-022, Westinghouse Hanford Company, Richiand, Washington.

McDonald, F. N., 1992, Project C-O18H Wastewater Engineering Alternatives Report, WHC-SD-CO18H-ER-001, Rev. 1, Westinghouse Hanford Company, Richland, Washington.

Nelson, D. A., S. D. Burton, J. B. Duncan, and G. A. Jensen, 1994, Separation of HTO from Water Using Membrane Technology, Proceedings of the 34 th Annual Conference of the Canadian Nuclear Society, Session 4C, Vol. II, Montreal, Quebec.

Nixon, P., L. St. Clair, and B. Wheat, 1991, Ground Water Extraction, Treatment and Upgradient Injection Systems Provide a Mechanism to Control Tritium Plumes at DOE Facilities, Westinghouse Savannah River Company, Aiken, South Carolina, Presented at "Environmental Remediation 91," Pasco, Washington, September 8-11, 1991.

Okada, S. and N. Momoshima, 1993, "Overview of Tritium: Characteristics, Sources, and Problems," in Health Physics, 65:595-609.

SAIC, 1994, International Survey of Tritium Emissions and Discharge from Nuclear Power Facilities, Science Applications International Corporation.

SEPA, 1993, State Environmental Policy Act Addendum to SEPA Determination of Significance: Supplemental Analysis of the 200 Area's Effluent Treatment Facility.

Siler, J. L., M. R. Poirier, D. J. McCabe, and T. C. Hazen, 1991, Fouling of Ceramic Filters and Thin-Film Composite Reverse Osmosis Membranes by Inorganic and Bacteriological Constituents, Westinghouse Savannah River Company, Aiken, South Carolina, Presented at the AICHE Summer National Meeting, Pittsburgh, Pennsylvania, August 18-21 1991.

Todaro, C., 1994, Private Communication, Westinghouse Savannah River Company, Aiken, South Carolina.

UNSCEAR, 1993, Report to the General Assembly: Sources and Effects of Ionizing Radiation, The United Nations Scientific Committee on the Effects of Atomic Radiation.

Vasaru, G., 1993, Tritium Isotope Separation, CRC Press, Ann Arbor, Michigan.

Villani, S., 1979, Uranium Enrichment, Springer-Verlag, Berlin, Germany.

Waters, E. D., 1988, Consideration of Disposal Alternatives for TritiumContaminated Wastewater Streams at Hanford, WHC-EP-0118, Westinghouse Hanford Company, Richland, Washington. 
Wittekind, W. D., 105N Basin Tritium Analysis Interpretation, (internal memo to D. L. Schilperoort, 1993) West inghouse Hanford Company, Richland, Weshington.

Woodruff, R. K. and R. W. Hanf, 1993, Hanford Site Environmental Report for Calendar Year 1992, PNL-8682, Pacific Northwest Laboratory, Richland, Washington. 
DOE/RL-94-77

APPENDIX A

TRI-PARTY AGREEMENT MILESTONE M-26-05A

TRITIATED WASTEWATER TREATMENT EVALUATION 
$\stackrel{P}{=}$

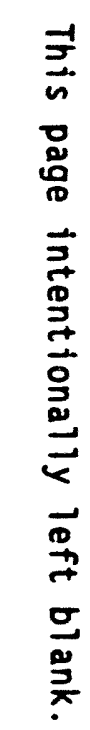


Federal Facility Agreement and Consent Order Change Control Form

Change Number: M-26-93-01

Originator: June M. Hennig 376-1366

Title: Tritiated Wastewater Treatment Evaluation

Description/Justification:

A technological solution needs to be found for controlling or removing residual tritium from water at the concentrations and quantities that presently exist in the environment or that will remain in liquid effluent streams after treatment. The two major applications for this treatment technology at the Hanford Site would potentially be the cleanup of tritium contaminated groundwater and wastewater that contains residual tritium after treatment (e.g., the 242-A Evaporator Process Condensate liquid effluent).

The DOE proposes that a Tri-Party Agreement interim milestone be established to provide a comprehensive annual review of the development status of tritium contaminated water treatment and control technologies. The summary report would be written in a nontechnical fashion and would contain a bibliography to reference technical reports, and would be less than 30 pages in length. The report should cover the following:

A. A brief background discussion about tritium, the Drinking Water Standards established for tritium by the Environmental Protection Agency and the environmental and health risks (short term and long term) associated with exposure to tritium.

B. A summary of the expected discharge of tritium contaminated wastewater from the 200 Area ETF and other current or future i iquid effluents that have tritium present in concentrations in excess of the Drinking Water Standards. This summary will include the expected concentration of tritium in the effluent after treatment, the expected volume of discharge, and the total curies of tritium expected to be discharged.

C. Summary of the extent of tritium contamination in the groundwater beneath the Hanford Site. This summary will describe the direction, speed, movement, and concentration gradients of the tritium ground water plume $(s)$.

D. A comparison of the extent of the tritium contamination, tritium control and treatment technologies, and permit conditions at the Hanford Site against other DOE sites.

E. A survey of the major permits granted for the disposal of tritiated wastewater. A comparison of the disposal mechanisms and permitting approach being used at other facilities in the United States disposing of tritiated discharges in concentrations in excess of the EPA Drinking Water Standards. The report will contain an evaluation 
and comparison of the permit conditions being imposed at these sites and release limits being used worldwide for tritiated wastewater discharges to the environment.

F. The current waste management practices and summary of technology development associated with tritium contaminated water currently used in:

- The DOE complex

- Commercial Nuclear Facilities within the U.S.

- internationally: Canada, France, Belgium, Germany, Japan, and Russia

G. The background and basis for continuing to discharge the tritiated wastewater to the soil column. This section should provide an analysis of the treatment technologies evaluated, the disposal options considered, and the basis for the selection of soil column disposal. Included should be the summary of the groundwater modeling done to select the site for disposal of the liquid effluent.

H. A discussion and status of tritiated water treatment and control technologies. An analysis of the application of sufficiently developed technologies to the tritium contamination issues at the Hanford Site. If the technologies appear feasible, develop a rough order of magnitude cost estimates and schedules for specific technology application at the Hanford Site.

I. An analyses of options for reuse of all or parts of the tritium contaminated waters at the site including, but not limited to, use as a feed water in sludge washing, cooling water in new facilities, or as hydraulic barriers for containment of more dangerous plumes.

The interim milestone:

M-26-05A Commencing Auqust 1994 and annually thereafter:

Submit to EPA and Ecology an evaluation of development status of tritium treatment technology that would be pertinent to the cleanup and management of tritiated wastewater (e.g., the 242-A Evaporator Process Condensate liquid effluent) and tritium contaminated groundwater at the Hanford Site. 
Impact of the Change:

This change will provide a regular comprehensive review of tritium control and treatment technologies that would be applicable for use at the Hanford Site. Tritium treatment technology will be reviewed for application to the treatment of tritium contaminated wastewater and tritium contaminated groundwater with the purpose of identifying solutions that look promising for large scale applications. Ecology, DOE, and EPA will work together to screen emerging promising technologies to identify those technologies suitable for bench and pilot-scale testing with Hanford Site contaminated water. If application of a technology is mutually agreed-upon, implementation (e.g., bench scale, pilot scale, full scale) of the technology will be incorporated into the Agreement Action Plan throligh negotiation. Timely resolution of these negotiations (within 6 months) is expected. Failure to complete negotiations within 6 months from annual report submission will result in dispute resolution. 
DOE/RL-94-77

This page intentionally left blank.

A-4 
DOE/RL-94-77

APPENDIX B

CONVERSION TABLES

$B-i$ 
$\stackrel{\text { I }}{=}$

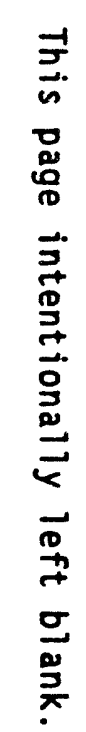


Table B-1. Units of Radiation Measure

\begin{tabular}{|lll|}
\hline Current System & Systeme International & Conversion \\
\hline curie $(\mathrm{C} i)$ & becquerei $(\mathrm{Bq})$ & $1 \mathrm{Ci}=3.7 \times 10^{10} \mathrm{~Bq}$ \\
rad (radiation absorbed dose) & gray $(\mathrm{Gy})$ & $1 \mathrm{rad}=0.01 \mathrm{~Gy}$ \\
rem (roentgen equivalent man) & sievert $(\mathrm{Sv})$ & $1 \mathrm{rem}=0.01 \mathrm{~Sv}$ \\
\hline
\end{tabular}

Table B-2. Radioactivity Level Conversions.

\begin{tabular}{|c|c|c|c|}
\hline $\mathrm{pCi} / \mathrm{L}$ & $\mu \mathrm{Ci} / \mathrm{L}$ & $\mathrm{Ci} / \mathrm{L}$ & $\mu \mathrm{Ci} / \mathrm{m}]$ \\
\hline $10^{4}$ & 0.01 & $10^{-8}$ & 0.00001 \\
\hline $10^{5}$ & 0.1 & $10^{-7}$ & 0.0001 \\
\hline $10^{6}$ & 1 & $10^{-6}$ & 0.001 \\
\hline $10^{7}$ & 10 & $10^{-5}$ & 0.01 \\
\hline $10^{8}$ & 100 & $10^{-4}$ & 0.1 \\
\hline $10^{9}$ & 1000 & $10^{-3}$ & 1 \\
\hline $10^{10}$ & 10,000 & $10^{-2}$ & 10 \\
\hline $10^{11}$ & 100,000 & $10^{-7}$ & 100 \\
\hline $10^{12}$ & $1,000,000$ & 1 & 1000 \\
\hline
\end{tabular}

Table B-3. Fractions and Multiples of Units.

\begin{tabular}{lrl}
\hline Multiple & Decimal Equivalent & Prefix \\
\hline $10^{12}$ & $1,000,000,000,000$ & tera \\
$10^{9}$ & $1,000,000,000$ & giga \\
$10^{6}$ & $1,000,000$ & mega \\
$10^{3}$ & 1,000 & kilo \\
$10^{2}$ & 100 & hecto \\
$10^{9}$ & 10 & deka \\
$10^{0}$ & 1 & \\
$10^{-1}$ & 0.1 & deci \\
$10^{-2}$ & 0.01 & centi \\
$10^{-3}$ & 0.001 & milli \\
$10^{-6}$ & 0.0000000001 & micro \\
$10^{-9}$ & 0.000000000001 & nano \\
$10^{-12}$ & 0.000000000000001 & pico \\
$10^{-15}$ & & femto \\
\hline
\end{tabular}

B-1 
DOE/RL-94-77

This page intentionally left blank. 


\section{DISTRIBUTION}

Number of Copies

\section{OFFSITE}

6

Washington Department of Ecology

P.0. Box 1386, MISN N1-05

Richland, WA 99352

David C. Nylander

Melodie Selby (2)

Alex B. Stone

P.0. Box 47600

Olympia, WA 98504-7600

Roger Stanley

Bob King

2

U.S. Environmental Protection Agency

EPA, Region 10

712 Swift Blvd., Suite 5

Richland, WA 99352

Doug Sherwood

1

Confederated Tribes of the Umatilla Reservation

P.0. Box 638

Pendelton, or 98701

J. R. Wilkinson

1

Nez Perce Tribal Office

P.0. Box 305

LaPwai, ID 83540

D. Powaukee

1

Yakama Indian Nation

2552 Haines

Richland, WA 99352

R. F. Cook

\section{ONSITE}

U.S. Department of Energy. Richland Operations Office

J. M. Hennig

J. E. Rassmussen

S7-55

S. H. Wisness

A. V. Beard

P. W. Willison

RL Public Reading Room

(2)

A5- 15

A5-15

S7-55

A4-52

Al-65

$$
\text { Distr-1 }
$$


Pacific Northwest Laboratory

J. L. Ethridge

R3-85

D. A. Nelson

P8-38

Hanford Technical Library

P8 55

2

Bechtel Hanford. Inc.

J. E. Nemec

H4-79

B. H. Ford

H6-06

30

Westinghouse Hanford Company

W. L. Allen

P. M. 01 son

J. D. Williams

A. J. Ciliberto

J. W. Cammann

D. L. Flyckt

B. F. Weaver

J. J. Luke

B. D. Williamson

T. B. Veneziano

G. 0 . Gesell

D. K. Tyler

S. D. Godfrey

D. D. Wodrich

J. L. Lee

J. C. Fulton

L. D. Arnold

F. M. Coony

P. J. Mackey

H. E. McGuire, Sr. Staff

H6-28

H6-28

H6-28

H6-32

H4-14

R3-45

T7-38

H6-25

B3-15

H6-10

H6-31

H6-06

B3-35

R2-85

$57-82$

R3-85

B2-35

H5-33

B3-15

R. E. Traister

B3-63

President's Office

B3-63

Central Files

B3-01

EPIC

(2)

Document Processing \& Dist (2)

L8-04

Information Release Admin (3)

H6..08

L8-15

L8-07 

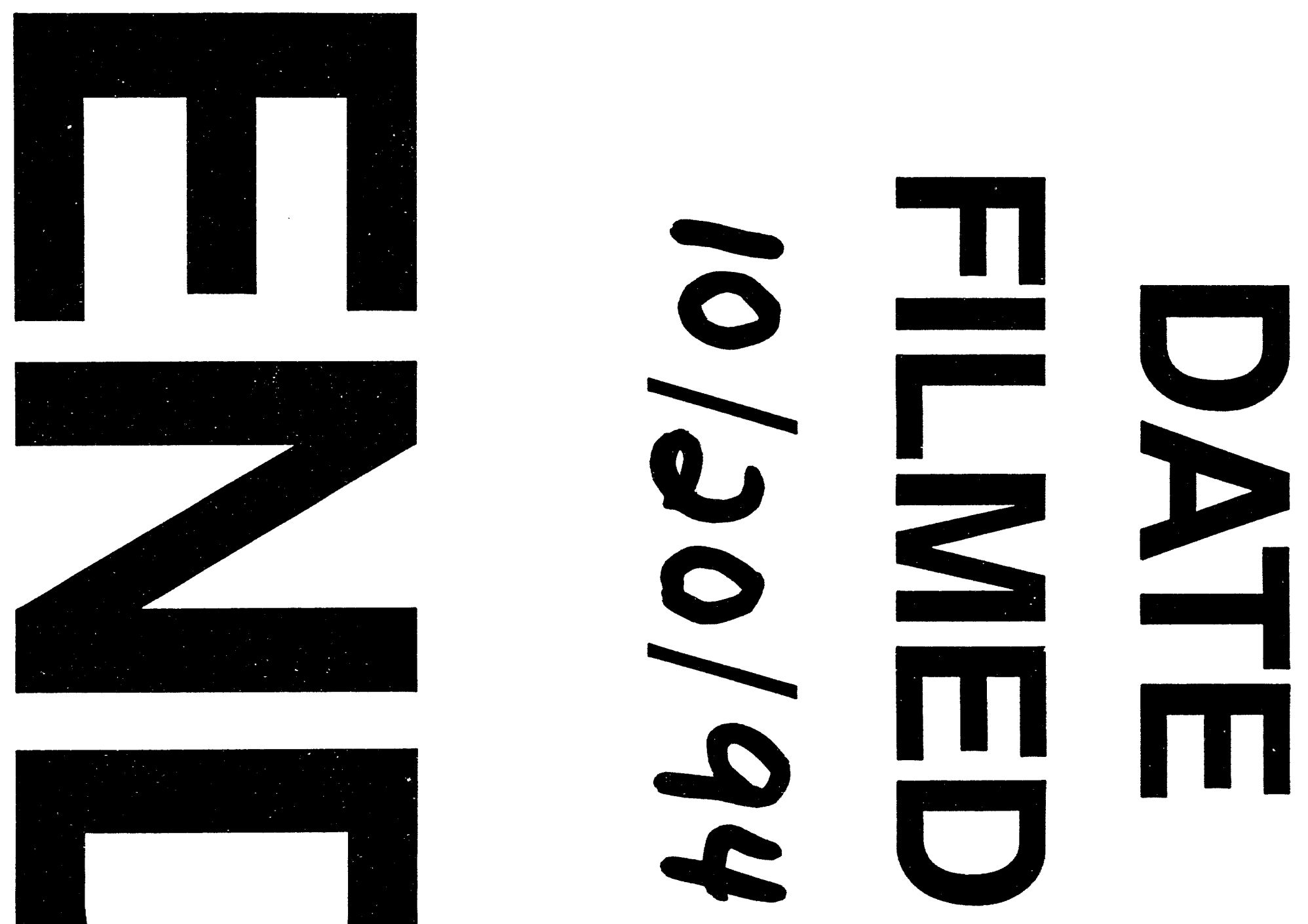
